\title{
Illegal Selective Logging and Forest Fires in the Northern Brazilian Amazon
}

\author{
Tiago M. Condé ${ }^{1,2, *\left(\mathbb{D}, \text { Niro Higuchi }^{2} \text { and Adriano J. N. Lima }\right.}{ }^{2}$ \\ 1 State University of Roraima (UERR), Department of Forest Engineering, 69373-000 Rorainópolis, Brazil \\ 2 Forest Management Laboratory (LMF), National Institute of Amazonian Research (INPA), \\ 69060-001 Manaus, Brazil; niro@inpa.gov.br (N.H.); adrianolmf@gmail.com (A.J.N.L.) \\ * Correspondence: tiagonafloresta@gmail.com; Tel.: +55-92-98102-3784
}

Received: 27 December 2018; Accepted: 11 January 2019; Published: 14 January 2019

\begin{abstract}
Illegal selective logging and forest fires occur on a large scale in the northern Brazilian Amazon, contributing to an increase in tree mortality and a reduction in forest carbon stock. A total of 120 plots of 0.25 ha ( 30 ha) were installed in transitional ecosystems or ecotones (LOt) between the forested shade-loving campinarana (Ld) and dense-canopy rainforest, submontane (Ds), in the National Forest (Flona) of Anauá, southern Roraima. Measuring the diameters at breast height $(\mathrm{DBH} \geq 10 \mathrm{~cm})$ and the heights of 171 dead trees (fallen naturally, illegally exploited, and affected by forest fires), enabled the estimation of carbon content from the application of a biomass equation developed at Manaus, and the calculation of a correction factor, using the average height of the largest trees. From 2015-2017, we mapped the real extent of illegal selective logging and forest fires across the region with CLASlite and INPE/Queimadas. From measurements of 14,730 live and dead trees across 30 hectares $\left(491 \pm 15\right.$ trees.ha $\left.{ }^{-1}\right)$, the illegal selective logging and associated forest fires, and aggravation by severe El Niño droughts resulted in an $8.2 \%$ mortality of trees $\left(40 \pm 9\right.$ dead trees.ha $\left.{ }^{-1}\right)$ and a $3.5 \%$ reduction in forest carbon stock $\left(6 \pm 3 \mathrm{Mg} \cdot \mathrm{ha}^{-1}\right)$ in the short-term. The surface area or influence of forest fires of very high density were estimated in the south-central region of Roraima $\left(8374 \mathrm{~km}^{2}\right)$ and the eastern region of the Flona Anauá $\left(37 \mathrm{~km}^{2}\right)$. Illegal selective logging and forest fires in forest areas totaled $357 \mathrm{~km}^{2}$ in the mosaic area, and $6 \mathrm{~km}^{2}$ within Flona Anaua. Illegal selective logging and forest fires in the years of severe El Niño droughts threatened the maintenance of environmental services provided by Amazonian forests.
\end{abstract}

Keywords: carbon; selective logging; fire; forest inventory; El Niño; tree mortality; Amazon forest

\section{Introduction}

Tropical forests account for more than half of the Earth's biodiversity [1], and they are considered to be important regulators of local and global climate through transpirational water flux, cloud formation, atmospheric circulation, and carbon storage [2]. Observations at tower and plot-scales (in situ), and satellite images have shown that tropical deforestation and forest degradation have resulted in increased temperatures and drought conditions, at both local and global scales [3-5]. The radiation balance at a the local-scale is strongly affected by fires, suffering a net loss of up to $70 \%$ of the photosynthetically active radiation at the surface, and directly influencing plant productivity [6]. The Amazonian hydroclimate is influenced by the textural roughness of the forest canopy [4], where intense selective logging has resulted in the formation of large clearings and increased tree mortality [7-9]. The remaining forest structure differs with regards to species composition and carbon stock, depending on the intensity of selective logging and timber productivity [7-10].

Illegal selective logging in tropical forests does not occur when environmental and social sustainability are prioritized, but only when short-term economic returns are sought. In contrast, legal 
selective logging with sustainable forest management or reduced-impact logging (RIL) focuses on the multiple use of timber and non-timber resources that are provided by forests, thereby preserving environmental services $[9,11,12]$. The long-term viability of the timber trade in the Brazilian Amazon depends on maintaining an adequate volume of legal timber extraction, whilst maintaining healthy forests [13]. Man's greed for the rapid and selective harvesting of high-value tropical timber as a commodity in the global marketplace has accelerated the loss of Amazonian habitats by deforestation and selective logging $[2,7,14]$, with critical consequences for flora and fauna, and contributions to severe climate change.

The indiscriminate use of fire by humans in areas of land-use conversion, from native forest to extensive ranching (cattle) and various agricultural uses, has contributed to an increase of burned areas inside and outside of the native forests of Roraima. The fuel of forest fires in Amazonia are residues that are left by illegal selective logging, fragmentation, and burned pastures $[15,16]$. In the past few decades, mega forest fires have been observed in the Amazon [3,17], specifically in Roraima [18-20], with strong interactions between the severity of El Niño droughts, and the occurrence of fires (drought-fire).

There is little scientific information on the impacts of illegal selective logging that are associated with the forest fires, on tree mortality and carbon stocks in the northern Amazon of Brazil. Fires alter forest characteristics, species diversity, structure, and composition, and they result in the strong selection of fire-adapted species. White-sand ecosystems represent the transitions or ecotones between campinaranas and dense rainforests in southern Roraima, with a high degree of flora endemism [21,22], and they are currently under strong pressure from the timber industry [23-25].

The objective of this research was to quantify the impacts of illegal selective logging and forest fires on tree mortality and carbon stock reduction in the National Forest (Flona) of Anauá in the southern Roraima. The hypothesis tested in this study was that there was a considerable increase in tree mortality and carbon stock reduction when illegal selective logging is associated with forest fires, particularly in years of severe El Niño droughts (2015-2017), in the northern Brazilian Amazon.

\section{Materials and Methods}

\subsection{Study Area}

Our study area was the National Forest (Flona) of Anauá, located in southern Roraima, in the northern Brazilian Amazon (Figure 1).

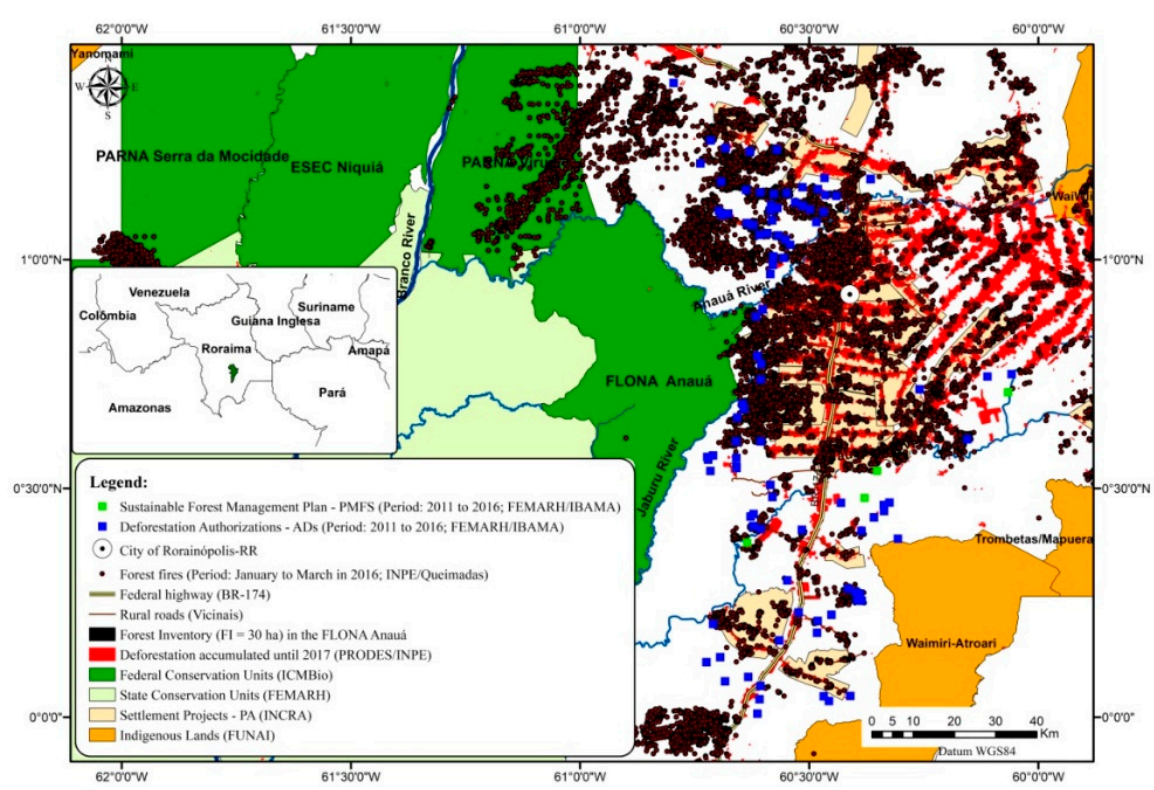

Figure 1. Study area: The National Forest (Flona) of Anauá in the northern Brazilian Amazon. 
The forest Anaua was legally declared a national forest in 2005, and it covers an area of approximately $2600 \mathrm{~km}^{2}$. It is an area protected by law [26] within the category of the sustainable use of natural resources, which allows for the legal exploitation of timber by Sustainable Forest Management Plans (PMFS) after approval of the Management Plan. In 2018, this Management Plan had not yet been completed. Consequently, illegal selective logging and associated forest fires has been observed more intensely in situ in the eastern region, due to its proximity to agrarian reform settlement projects, private rural properties, rural roads, and a federal highway (BR-174).

The history of changes in land use and land cover, and timber exploitation in southern Roraima (mosaic area: 66,928 km² ; State of Roraima: 224,396.8 $\mathrm{km}^{2}$ ) was spatially evaluated between 2011 and 2016 by the Deforestation Authorizations (ADs = 103) and Sustainable Forest Management Plans (PMFSs $=4$ ) issued by the environmental agencies: the State Foundation for the Environment and Water Resources of Roraima (FEMARH) and the Brazilian Institute of Environment and Renewable Natural Resources (IBAMA) [27]. Monitoring of forest fires by the National Institute for Space Research (INPE) from January to March in 2016 demonstrated the penetration of fire in Flona Anauá (Figure 1, see Supplementary Materials: Figure S1).

\subsection{Data Collection}

A forest inventory (FI) was carried out from 2014 to 2017 by a team from the Forest Management Laboratory of the National Institute of Amazonian Research (LMF/INPA) (Figure 2). A total of 120 plots of 0.25 ha (30 ha total) were installed. We measured the diameter at breast height $(\mathrm{DBH} \geq 10 \mathrm{~cm})$ of trees in transitional ecosystems, or ecotones (LOt), between forested shade-loving campinarana (Ld) and dense-canopy rainforest, submontane (Ds), within Flona Anauá, and classified them according to the Brazilian Institute of Geography and Statistics (IBGE) [28]. The ecotones refer to regions of contact between two different ecosystems.

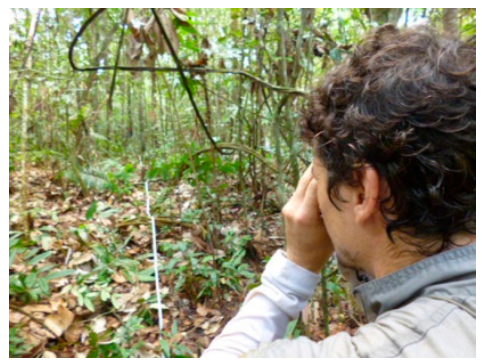

(a)

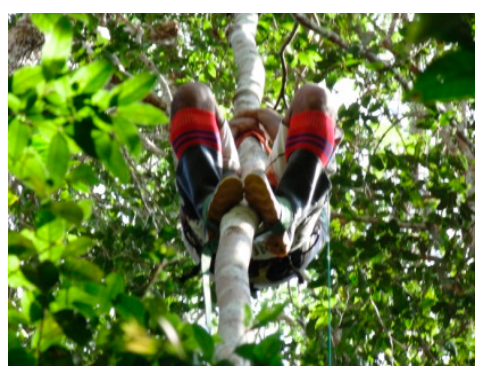

(d)

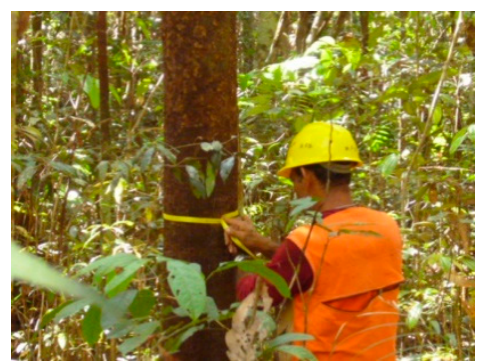

(b)

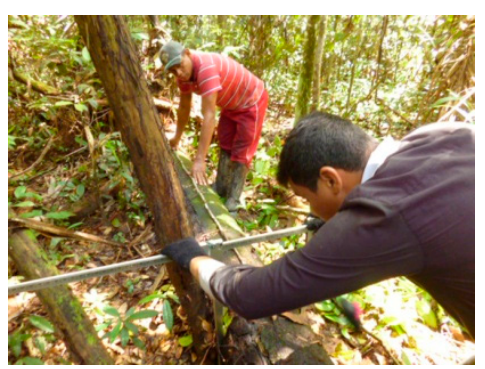

(e)

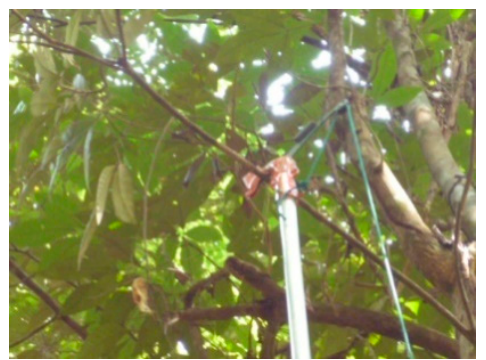

(c)

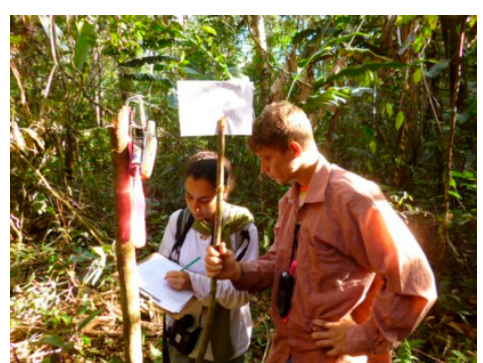

(f)

Figure 2. Forest inventory (FI) in Flona Anauá, northern Amazonia of Brazil: (a) Installation of plots (0.25 ha) with a compass and metric tape; (b) Measurement of the diameters of trees at breast height $(\mathrm{DBH} \geq 10 \mathrm{~cm})$; (c) Collection of tree branches for botanical identification; (d) The use of "peconha" for branch collection; (e) Measuring the diameters (calipers: Haglöf) and lengths or heights (metric tape) of dead trees (naturally fallen, illegally exploited, and affected by forest fires); (f) Georeferencing of FI plots and trees positions. 
The vegetation cover map from Brazilian Institute of Geography and Statistics - IBGE (https: / / portaldemapas.ibge.gov.br/; scale of 1:250,000) was used in FI planning (Figure 3). The primary units of the conglomerates were randomly installed within the ecotone areas (LOt), from a mapped polygon vector based on Landsat 8 (OLI) satellite images. This area covers approximately 76,681 ha $\left(767 \mathrm{~km}^{2}\right)$, occupying $29 \%$ of the total area of Flona Anauá. Four conglomerates with a standard "cross" format containing 20 plots were installed. Three conglomerates with different formats were installed, but maintaining the plot's dimensions (tertiary units of $0.25 \mathrm{ha}$ ). The use of 0.25 ha plots has been recommended for forest inventories in tropical ecosystems, due to a greater accuracy in representing the forest structure [29-31]. An analysis of variance (ANOVA) for the density of the trees (trees $\left.\cdot \mathrm{ha}^{-1}\right)$ and the forest carbon stock $\left(\mathrm{Mg} \cdot \mathrm{ha}^{-1}\right)$ established that there are no requirements $(p>0.05)$ for a stratified sampling design across the two ecosystems (Forested shade-loving campinarana (Ld) and dense-canopy rainforest, submontane (Ds)).

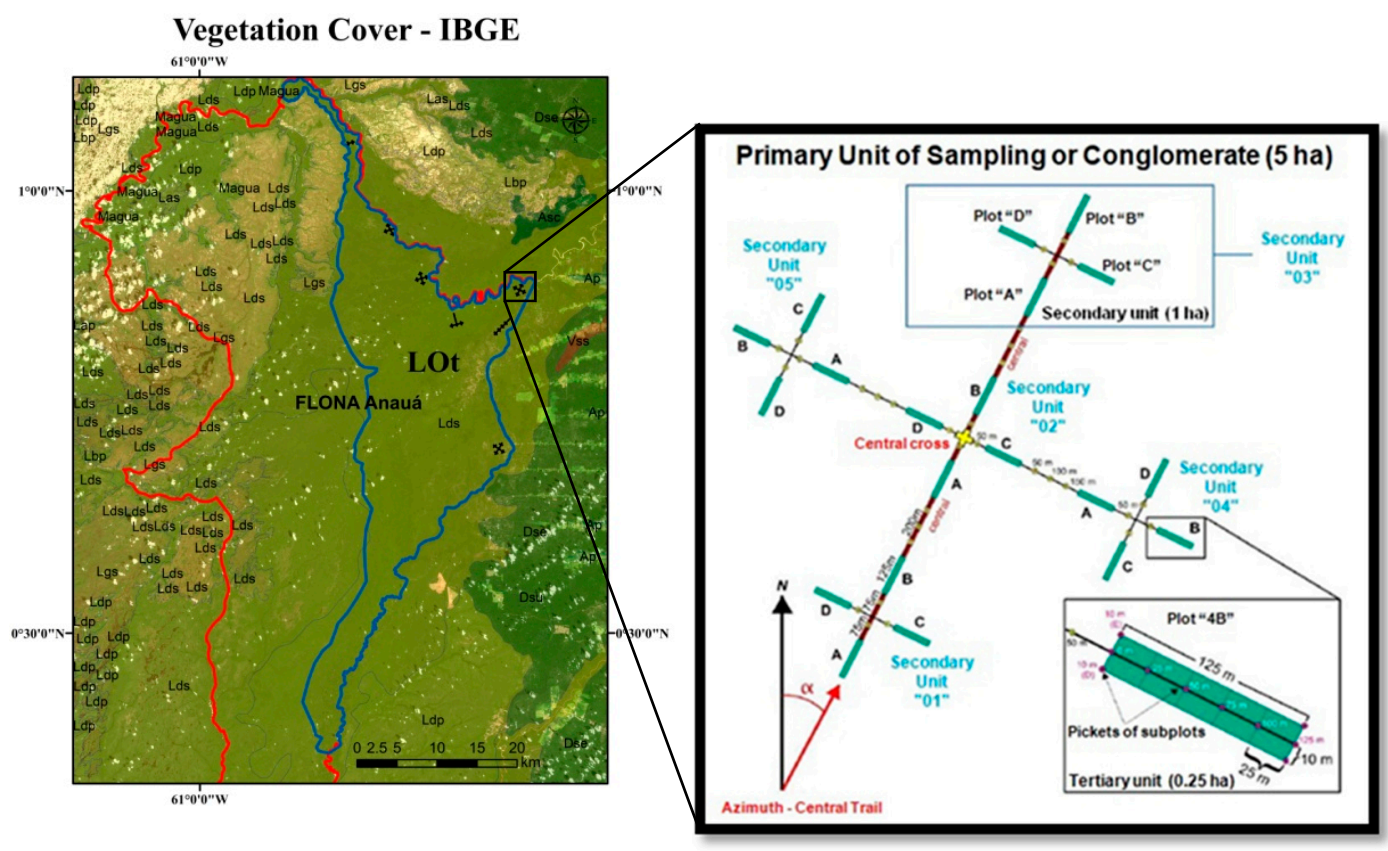

Figure 3. Forest inventory (FI) done by sampling in conglomerates (standard "cross" format) of Flona Anauá in the northern Brazilian Amazon. Vegetation cover map from IBGE (https:/ / portaldemapas. ibge.gov.br/) with transparency (70\%) of image by Landsat 8 (OLI) from the period 01/10/2017. Legend: Forested areas with large trees [28]: Dense-canopy rainforest, submontane (Ds); Forested shade-loving campinarana (Ld); Ecotones (LOt), among others. Non-forest areas with the presence of small trees, shrubs, herbs and grasses [28]: Grassy-woody shade-loving campinarana (Lg); Shrubby shade-loving campinarana (Lb); Treed shade-loving campinarana (La), among others.

In the timber measurement (TM) stage, we measured the diameters and heights of 171 dead trees (naturally fallen, illegally exploited, and affected by forest fires) (Figure 4). The selection of trees was based on the results from the forest inventory, observing the classical pattern of the negative exponential distribution of tree diameters in native forests in the Amazon [32-34]. Species identifications were confirmed by the Herbarium of INPA (see Supplementary Materials: Table S1). DBH and dominant height data were used to estimate forest carbon stocks from biomass equations. 


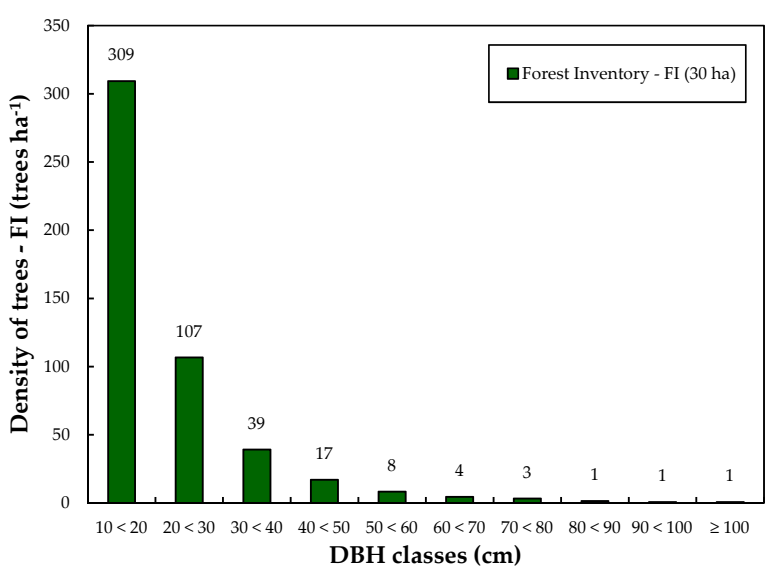

(a)

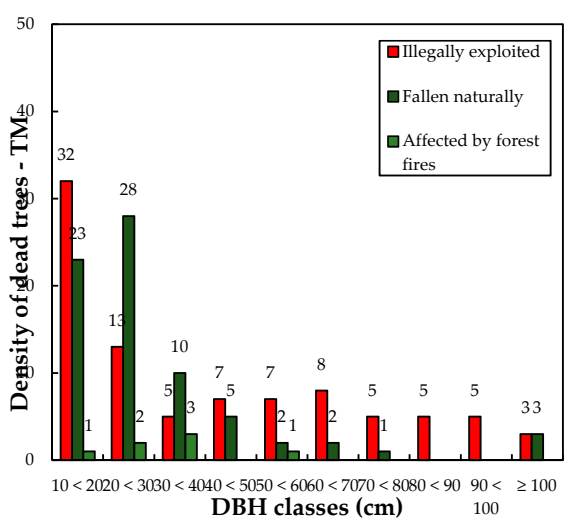

(b)

Figure 4. Densities of trees on Flona Anauá, southern Roraima: (a) Mean tree density per diameter class per hectare in the forest inventory (FI); (b) Mean dead tree density per diameter class in the timber measurement (TM) stage: Illegally exploited; Fallen naturally; Affected by forest fires.

\subsection{Carbon from the Biomass Equation and the Use of the Correction Factor of the Dominant Height}

The carbon stored in trees was estimated in three stages. Initially, estimates of the total fresh biomass (the sum of the above-ground and below-ground biomasses) were estimated from equations developed by the LMF/INPA for Central Amazonia at Manaus, AM, for Ds, method described by Silva in 2007 [30]. The correction factor for the average of the dominant height $\left(\mathrm{H}_{\mathrm{dom}}\right.$. $)$ of $20 \%$ of the trees with the largest diameters [31] were developed according to the equations below:

$$
\mathrm{FC}=\frac{\mathrm{H}_{\text {dom. (Flona Anauá) }}}{\mathrm{H}_{\mathrm{dom} \cdot(\mathrm{ZF}-2 / \mathrm{LMF} / \mathrm{INPA})}}=\frac{33.2}{30.2}=1.098023
$$

where FC is the correction factor of the dominant height in transitional ecosystems or ecotones (LOt) between the forested shade-loving campinarana $(\mathrm{Ld})$ and the dense-canopy rainforest, submontane (Ds) on Flona Anauá. $\mathrm{H}_{\mathrm{dom} \text {.(Flona Anauá) }}$ is the dominant height average of $20 \%$ of the largest trees in TM on Flona Anauá; $\mathrm{H}_{\mathrm{dom}}$.(ZF-2/LMF/INPA) is the dominant height average of $20 \%$ of the largest trees in ZF-2/Manaus, AM.

In the second stage, we estimated the dry biomass with the use of a correction factor based upon the water content in the trees developed by the LMF/INPA. We applied a factor of 0.582 , the average of the factors developed for Ds [30] and Ld [31]. Finally, the carbon present in the trees was estimated on the basis of the specific carbon contents of wood, according to LMF/INPA. We applied a factor of $0.480 \%$, an average of the factors developed for Ds [30] and Ld [35].

\subsection{Tree Mortality and Carbon Stock}

Estimations of the increase in tree mortality and the decrease in forest carbon stock were made in three stages. In the first, the forest inventory (FI) database was used to identify dead trees that died through natural processes (naturally fallen) and dead trees affected by human process (illegally exploited and affected by forest fires), excluding live trees (Figure 5). Subsequently, individual tree carbon values were estimated from a biomass equation developed at Manaus, AM (LMF/INPA), using a correction factor derived from the average of the dominant height of the trees in Roraima. Finally, we estimated the impact of illegal selective logging and forest fires on the increase of tree mortality, and subsequent decreases in forest carbon stock in the Flona Anauá. Mean values and 95\% confidence intervals $\left(\mathrm{CI}_{95 \%}\right)$ were estimated per hectare and population [36] (see Supplementary Materials: Equations S1; method described by Soares et al. in 2011, p. 163-174)). We assumed in this study that the reduction of the forest carbon stock arising through natural processes would be slow, 
changing the gas exchange of the forest ecosystem in the medium- and long-term. Dead trees that have naturally fallen will keep their carbon stored for a long time, without considerable losses from the forest. Trees that have naturally fallen are generally not removed from the forest by loggers, because they has low commercial value, due to their decomposition state. In contrast, trees affected by illegal selective logging results in an effective loss of forest carbon stock in the short-term. These trees are immediately extracted, and processed at local sawmills. Forest fires alter the gas exchange of the forest ecosystem in the short term, reducing the forest carbon stock to different degrees, according to fire incidence [15-17].

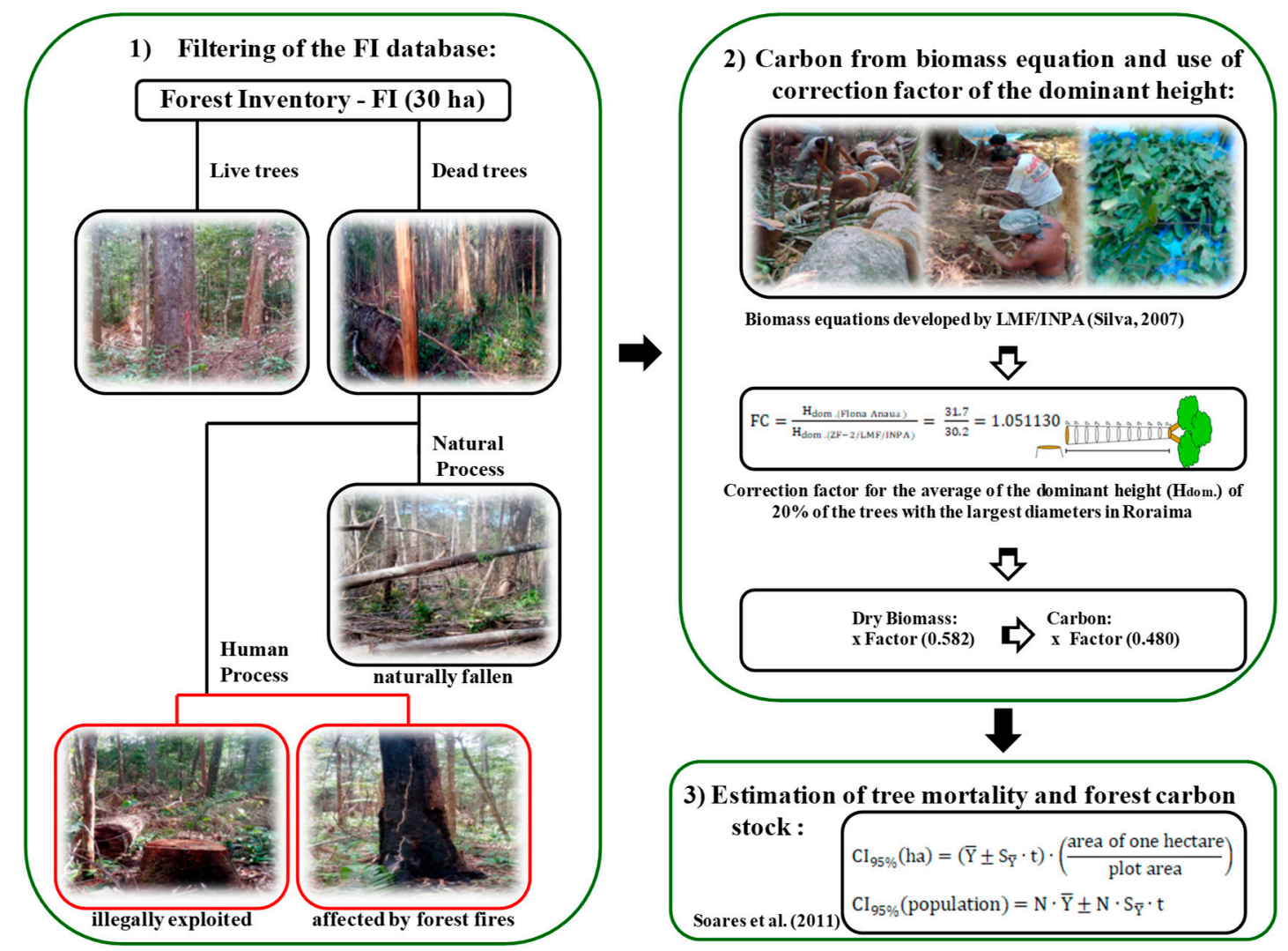

Figure 5. Flowchart of steps to obtain estimates of tree mortality and forest carbon stocks in Flona Anauá, northern Brazilian Amazon.

2.5. Mapping of Illegal Selective Logging and Forest Fires with Claslite and INPE/Queimadas, and Restrictions due to Forest Physiognomy

Using a combination of CLASlite [37] with INPE/Queimadas [38], with restriction per forest physiognomy, we mapped the surface area or the influence (total area), and the effective area of illegal selective logging associated with forest fires (Figures 6-10). CLASlite integrates a series of processes that take raw satellite imagery and that produce forest cover change images [37]. These processes can be summarized thus: (1) radiometric calibration and atmospheric correction of satellite data; (2) cloud, water, and shadow masking; (3) decomposition of image pixels into fractional surface covers; and (4-5) classification of the imagery into forest cover, deforestation, and forest disturbance (illegal selective logging in this study). Two scenes (Mosaic) of the remote sensor Landsat 8 (OLI; Path: 232; Rows: 059-060; area: 66,928 km²; Period: 04 October 2015 to 10 January 2017) obtained from the USGS website (https: / / earthexplorer.usgs.gov/) were used by CLASlite 3.2 for mapping the total area of illegal selective logging in southern Roraima, Brazil (Figure 6). 


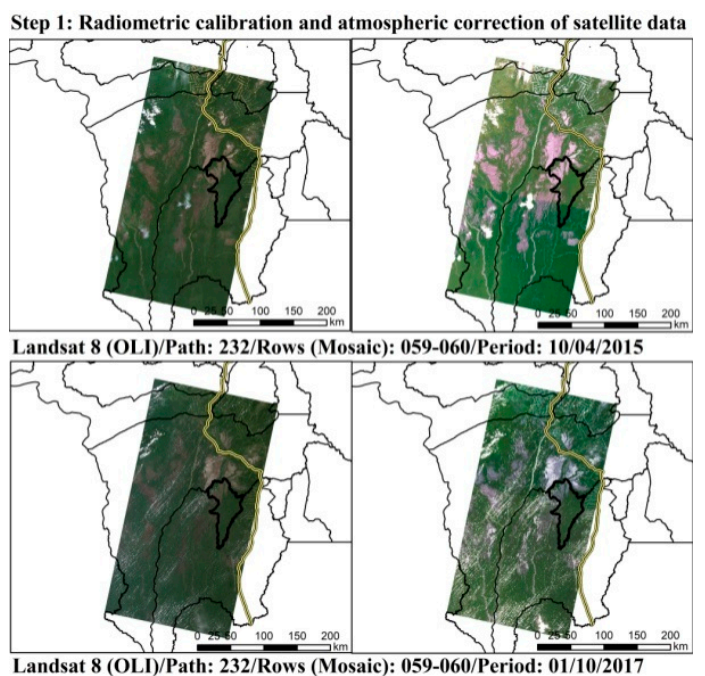

(a)

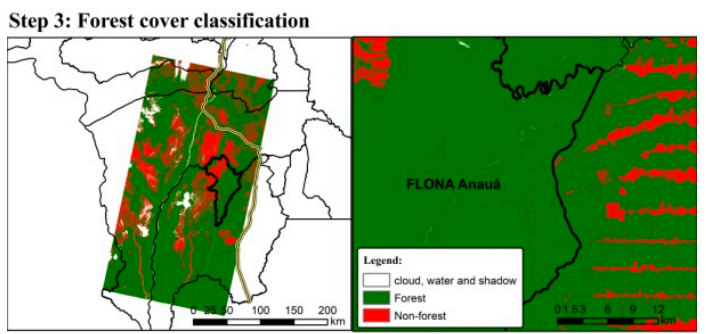

Landsat 8 (OLI)/Path: 232/Rows (Mosaic): 059-060/Period: 10/04/2015

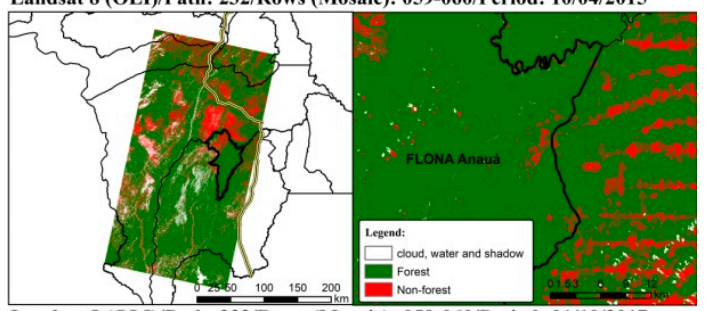

Landsat 8 (OLI)/Path: 232/Rows (Mosaic): 059-060/Period: 01/10/2017

(c)
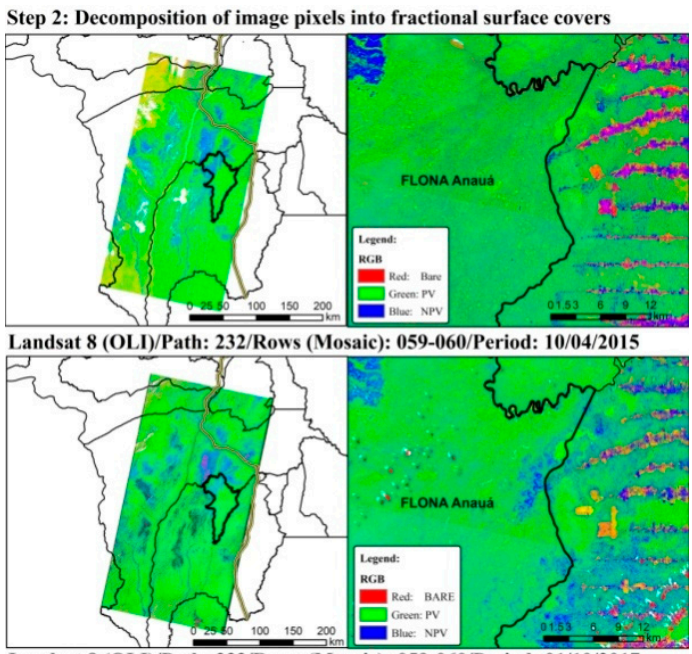

Landsat 8 (OLI)/Path: 232/Rows (Mosaic): 059-060/Period: 01/10/2017

(b)
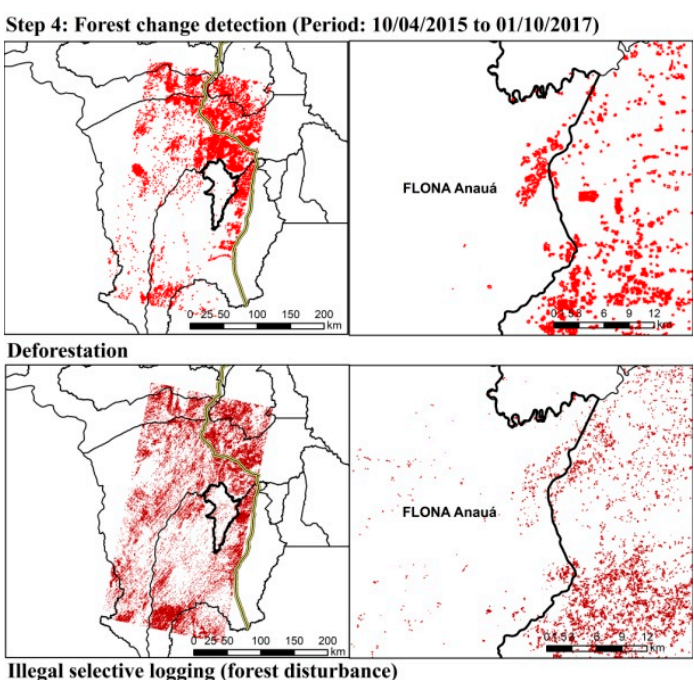

(d)

Figure 6. Flowchart of the steps with CLASlite for mapping illegal selective logging in southern Roraima, Brazil: (a) Radiometric calibration and atmospheric correction of the satellite data (including cloud, water, and shadow masking); (b) Decomposition of image pixels into fractional surface covers (photosynthetic vegetation-PV; non-photosynthetic vegetation-NPV and bare substrate-BARE); (c) Forest cover classification; (d) Forest change detection (deforestation and illegal selective logging or forest disturbance).

CLASlite mapped without discrimination the illegal selective logging as any type of intensity of forest disturbance, differing only from deforestation (clear cut). CLASlite has its own spectral library, so we created one restriction by forest physiognomy, derived of the vegetation cover map from IBGE (Scale 1:250.000; https:/ / portaldemapas.ibge.gov.br/), to perform the overlapping of CLASlite results (Figure 7a). Thus, we assume that in forest areas (large trees), illegal selective logging was quantified as being associated or not with forest fires [28]: Dense-canopy rainforest, submontane (Ds), forested shade-loving campinarana (Ld), transitional ecosystems or ecotones (LOt), among others (Figure 7b,c). In non-forested areas, with the presence of small trees, shrubs, herbs, and grasses, forest disturbances were quantified as being probably associated with forest fires, without illegal selective logging [28]. Non-forested areas were represented by grassy-woody shade-loving campinarana (Lg); shrubby shade-loving campinarana (Lb); treed shade-loving campinarana (La), among others (Figure 7b,d). Both forest disturbances were confirmed by validations in field (in situ) observations. 


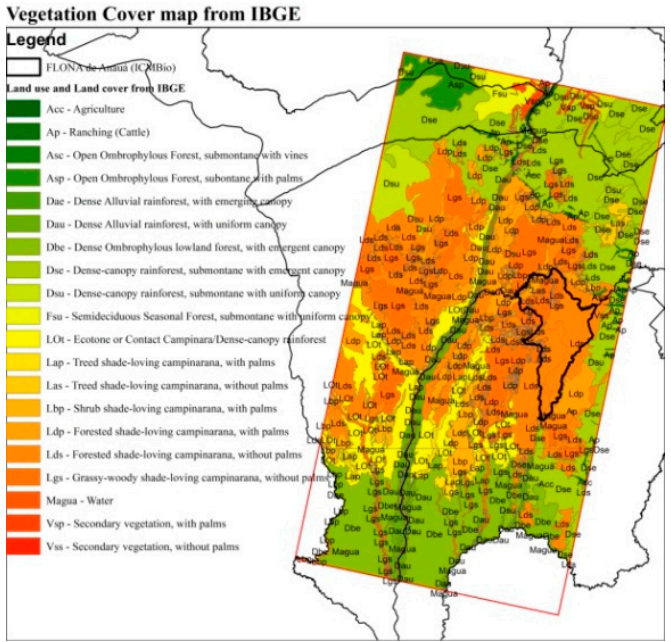

(a)

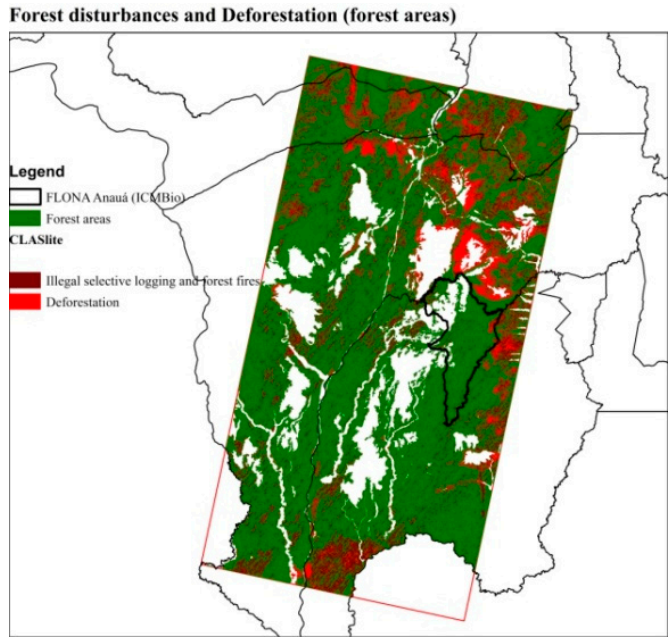

(c)

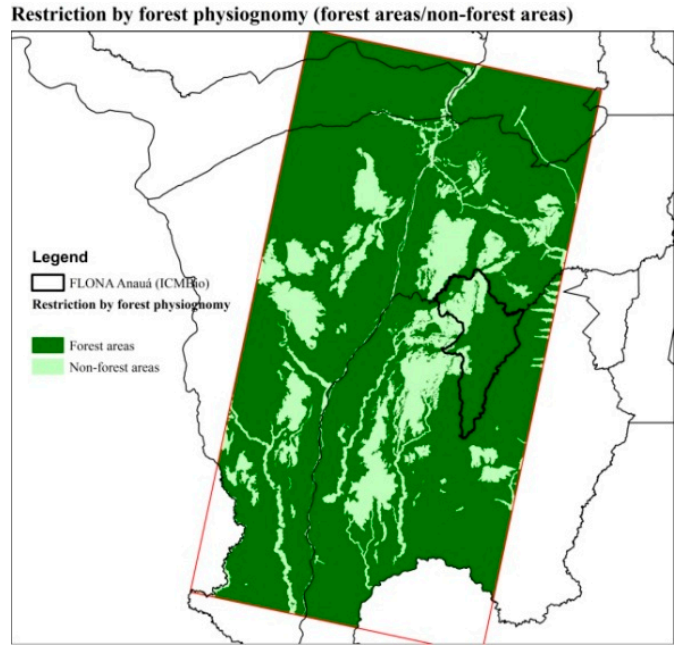

(b)

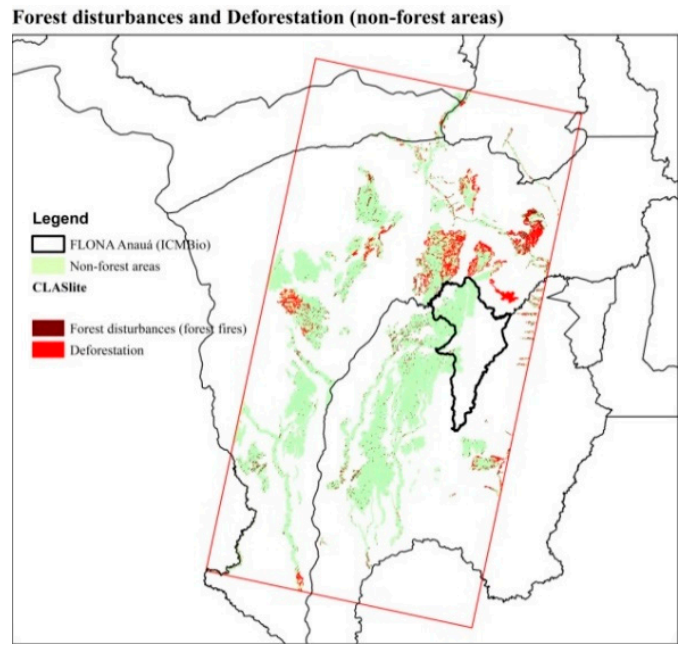

(d)

Figure 7. Restriction by forest physiognomy (forest area/non-forest area) derived from the vegetation cover map from IBGE to perform the overlapping of CLASlite results: (a) Cover map from IBGE; (b) Restriction by forest phytophysiognomy (forest areas/non-forest areas); (c) Overlapping of CLASlite results in forest areas: forest disturbances and deforestation; (d) Overlapping of CLASlite results in non-forest areas: forests disturbances and deforestation.

In this study, we considered all selective logging from illegal sources for three reasons (Figure 8): (a) Within the Flona Anauá area, any selective logging is illegal, because this conservation unit does not yet have an approved Management Plan [26]; (b) Outside the Flona Anauá area in agrarian reform settlement projects and private rural properties with ADs, this environmental license was not used for deforestation (clear cut) for cattle ranching or agriculture implementation (as registered in ADs), but spatial patterns characteristic of the illegal selective logging were still observed; (c) Outside the Flona Anauá area in PMFSs, observed deforestation was associated with illegal selective logging in spatial patterns that did not characterize either legal selective logging or RIL, and they contained associated deforestation. The finding of these illegal activities was confirmed by field (in situ) observations of a complete absence of RIL techniques that are obligatory when sustainable forest management is authorized by competent environmental agencies in Brazil. We detected extensive forest degradation, excluding the possibility of the selective extraction of legal timber. We performed an accuracy assessment of the mapping by CLASlite per-control samples (CS $=400$ total; validation in situ) (Figure 8d) by calculating the error matrix, and the general hits of the user (Producer), and Kappa index or Kappa coefficient [39]. 


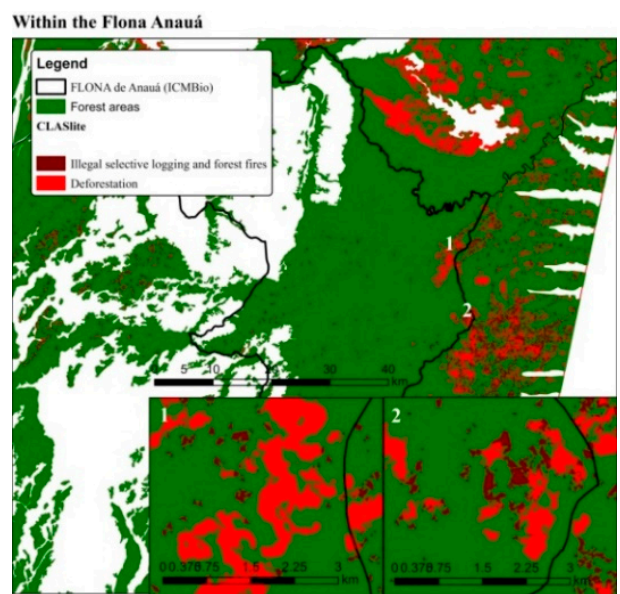

(a)

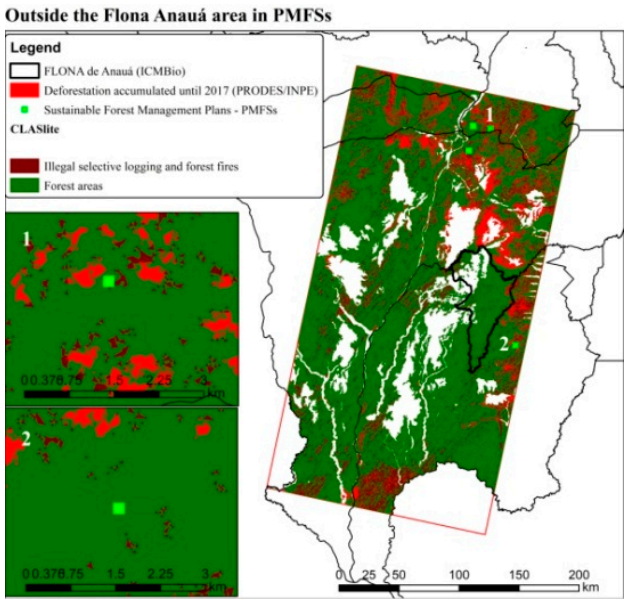

(c)

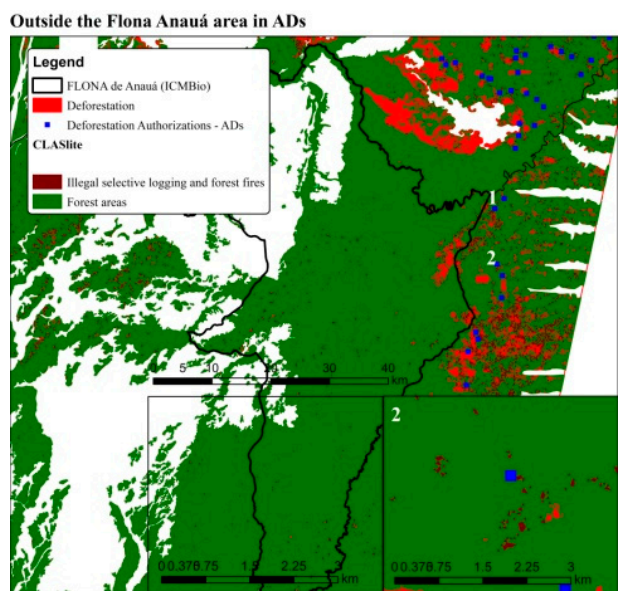

(b)

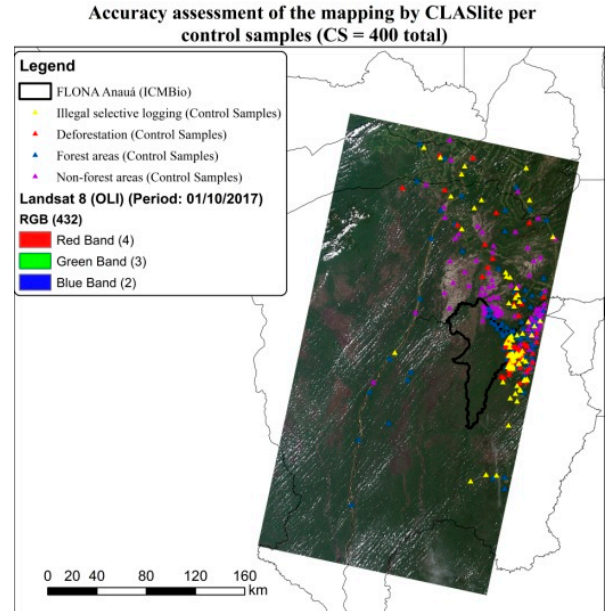

(d)

Figure 8. Analysis of the spatial pattern of illegal selective logging in the northern Brazilian Amazon: (a) Within the Flona Anauá; (b) Outside the Flona Anauá area in deforestation authorizations (ADs);

(c) Outside the Flona Anauá area in Sustainable Forest Management Plans (PMFSs); (d) Accuracy assessment of the mapping performed by CLASlite per CS (Landsat 8/OLI; Period: 10 January 2017).

We identified the locations of fires on a monthly basis (burning spots $=76,018$ ) by using the program INPE/Queimadas [38] for the State of Roraima (area: 224,300.8 km² ; period: Period: 04 October 2015 to 04 January 2017; and satellites Aqua and, Terra, GOES-13, NOAA-15, NOAA-18, NOAA-19, NPP) for generating the annual kernel density map after several tests (burning spots = 68,296; Period: 04 January 2016 to 04 January 2017; cell size: $0.02\left(6.25 \mathrm{~km}^{2}\right)$; search radius: 0.1 ; mask: State of Roraima; satellites: Aqua, Terra, GOES-13, NOAA-15, NOAA-18, NOAA-19, NPP), and to determine the surface area or influence (total area) of forests fires (Figure 9). 


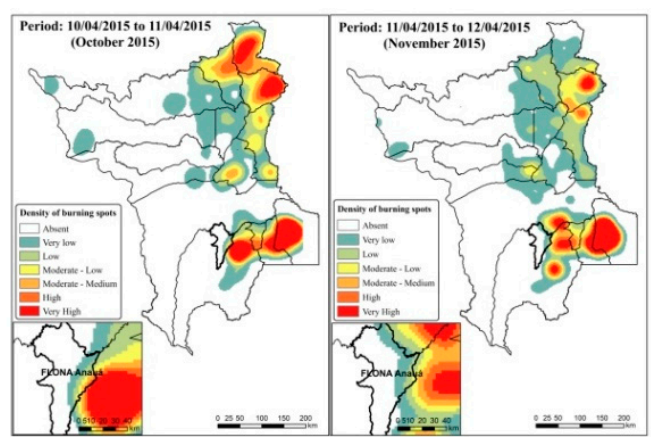

(a)

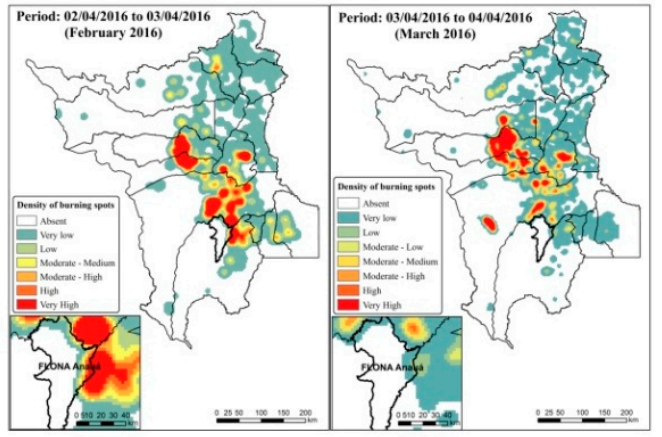

(e)

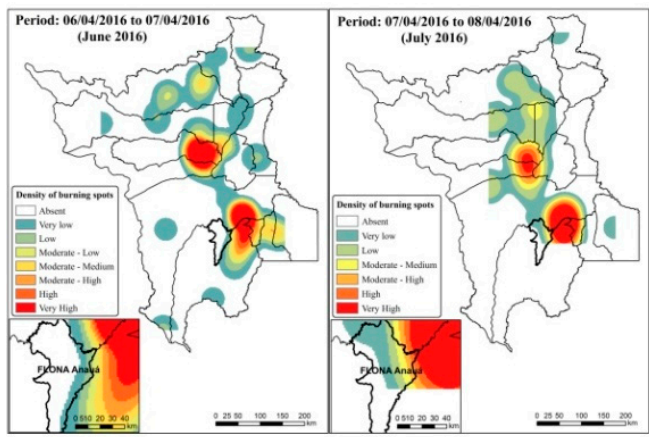

(i)

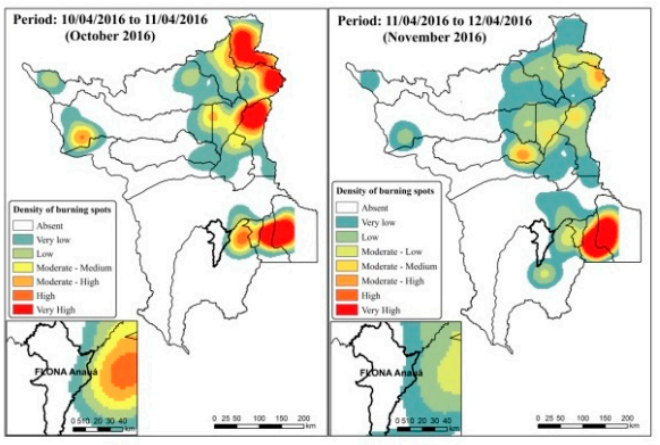

(m) (b)

(f)

(j)

(n)

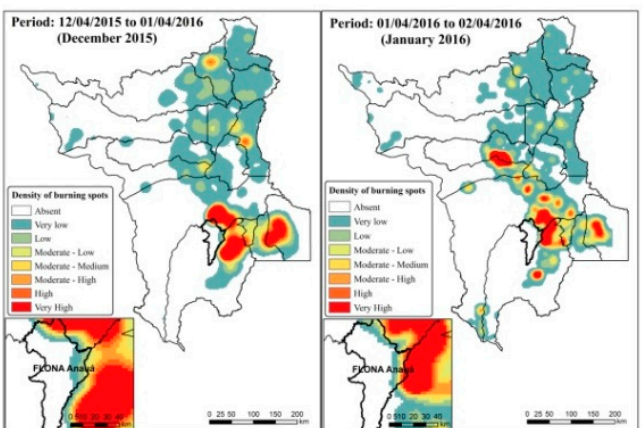

(c)

(d)

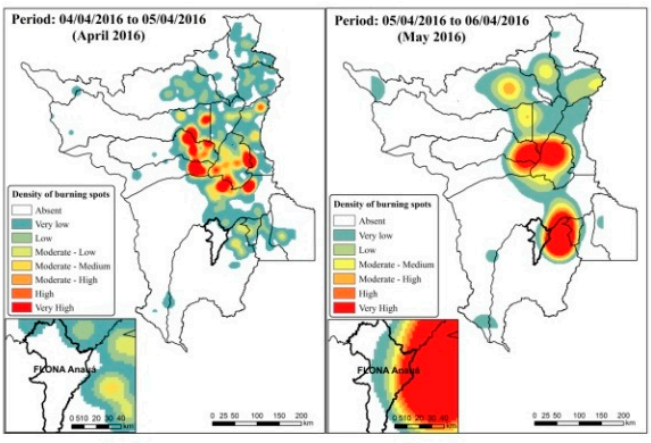

(g)

(h)

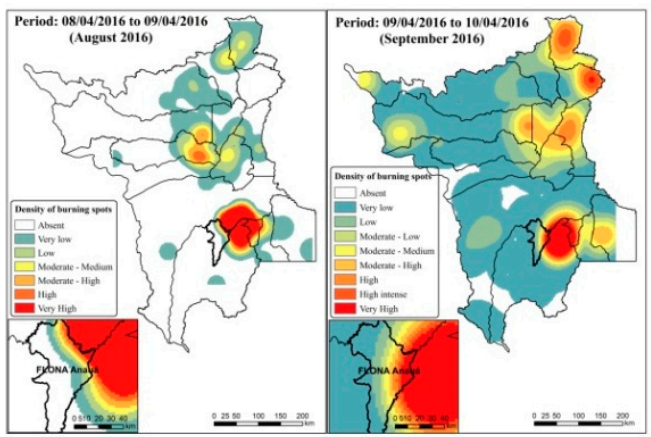

(k)

(1)

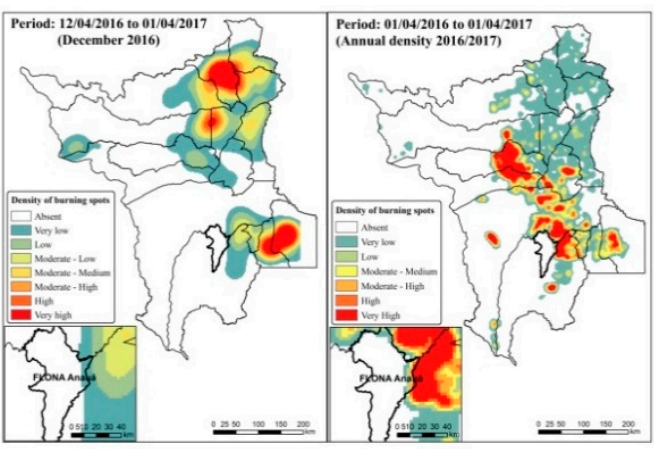

(o)

Figure 9. Monthly estimates and annual density of forest fires in the State of Roraima: (a) October 2015; (b) November 2015; (c) December 2015; (d) January 2016; (e) February 2016; (f) March 2016; (g) April 2016; (h) May 2016; (i) June 2016; (j) July 2016; (k) August 2016; (1) September 2016; (m) October 2016; (n) November 2016; (o) December 2016; (p) Annual density, 2016/2017. Burning spots were obtained from the program INPE/Queimadas (http:/ / www.inpe.br/queimadas/portal). 
The fire incidence is a reflection of the density of fires mapped by INPE/Queimadas, accumulated in each region, calculated by the kernel density map (see Supplementary Materials: Equations S2). The density of the burning spots was classified as: Absent, Very low, Low, Moderate-Low, Moderate-Medium, Moderate-High, High, High Intense, and Very High, thereby combining the information generated by CLASlite with INPE/Queimadas, in order to map the surface area or influence (total area) and the effective area of illegal selective logging associated with forest fires in southern Roraima (Figure 10).

The surface or influence (total area) and effective area of illegal selective logging with forest fires

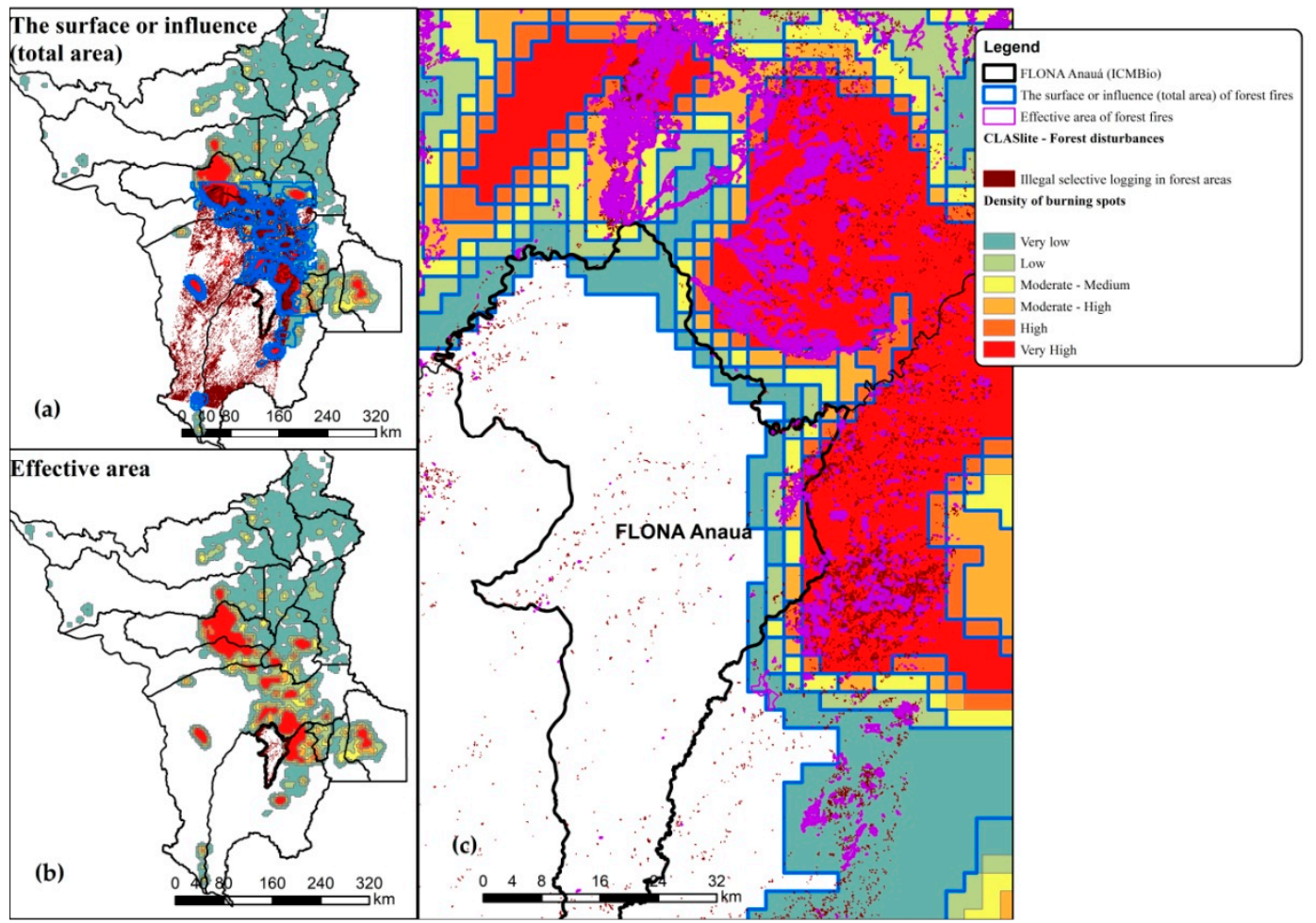

Figure 10. Mapping the surface area or influence (total area) and the effective area of illegal selective logging with forest fires in southern Roraima, thereby combining the information generated by CLASlite with INPE/Queimadas: (a) The surface area or influence (kernel density-burning spots; spatial resolution of $2472 \mathrm{~m}$ ); (b) Effective area (spatial resolution of $30 \mathrm{~m}$ ); (c) The surface area or influence, and the effective area within and outside Flona Anauá.

The association of illegal selective logging with forest fires in this study was undertaken to account for two important facts found in the field: (1) we observed that after illegal selective logging inside and outside Flona Anauá, some areas were burned, making it difficult to trace these activities, leaving the impression that these forest fires were the only cause of this forest disturbance; (2) the practice of burning after the conversion of forest (illegal selective logging and deforestation) to pasture and agriculture was observed in several rural properties around Flona Anauá, generating large forest fires, thereby providing confirmation of the fires identified from INPE/Queimadas. According to these rural producers, this represents the least onerous way of undertaking cattle ranching and agriculture in the Amazon.

\section{Results}

\subsection{Forest Inventory (FI) and Timber Measurement (TM)}

A total of 14,730 trees with $\mathrm{DBH} \geq 10 \mathrm{~cm}$ were measured in the 30 hectares of plots used for the forest inventory (FI) surveys between 2014 and 2017 in Flona Anauá, southern Roraima. The mean 
tree density was $491 \pm 15$ trees ha ${ }^{-1}\left(\mathrm{CI}_{95 \%}\right)$, and the mean diameter $(\mathrm{DBH})$ was $21 \pm 0.3 \mathrm{~cm}\left(\mathrm{CI}_{95 \%}\right)$, with a range of 10-180 cm (Table 1). From timber measurements (TM), the mean tree diameter (DBH) was different and ranged from 10-126 cm (Table 1). The total height $(\mathrm{H})$ ranged from 8 to $54 \mathrm{~m}$. The dominant height $\left(\mathrm{H}_{\mathrm{dom}}\right)$, which is defined as the average of $20 \%$ of the largest trees, ranged from 26-54 m. The correction factor for Flona Anauá based on $H_{\mathrm{dom}}$. was estimated at $\mathrm{FC}=1.098023$.

Table 1. Mean tree density, diameter $(\mathrm{DBH})$, total height $(\mathrm{H})$, and dominant height $\left(\mathrm{H}_{\mathrm{dom}}\right)$ in the forest inventory (FI), and timber measurement (TM) in the northern Brazilian Amazon.

\begin{tabular}{|c|c|c|c|c|c|}
\hline \multirow{2}{*}{ Forest Phytophysiognomy ${ }^{1}$} & \multicolumn{2}{|c|}{ Forest Inventory (FI) } & \multicolumn{3}{|c|}{ Timber Measurement (TM) } \\
\hline & Density (trees $\cdot \mathrm{ha}^{-1}$ ) & DBH (cm) & $\mathrm{DBH}(\mathrm{cm})$ & $\mathrm{H}(\mathrm{m})$ & $\mathrm{H}_{\text {dom. }}(\mathrm{m})$ \\
\hline $\begin{array}{l}\text { LOt }^{2} \text { Forested shade-loving campinarana } \\
\text { (Ld)/Dense-canopy rainforest submontane (Ds) }\end{array}$ & $491 \pm 15$ & $21 \pm 0.3$ & $37 \pm 5$ & $21 \pm 1$ & $33 \pm 1$ \\
\hline
\end{tabular}

${ }^{1}$ Forest phytophysiognomy classified according to IBGE (2012); ${ }^{2}$ Transitional ecosystems or ecotones; Mean values and $95 \%$ confidence intervals $\left(\mathrm{CI}_{95 \%}\right)$.

\subsection{Tree Mortality and Forest Carbon Stock}

The forest of Flona Anauá had an average tree density of $491 \pm 15$ trees ha ${ }^{-1}\left(\mathrm{CI}_{95 \%}\right)_{\text {, }}$ corresponding to a mean forest carbon stock of $157 \pm 5 \mathrm{Mg} \cdot \mathrm{ha}^{-1}$, and a total C stock (LOt: $\left.76,681 \mathrm{ha}\right)$ of $12.1 \pm 0.4 \mathrm{Tg}\left(\mathrm{CI}_{95 \%}\right)$. Illegal selective logging and forest fires resulted in a $48 \%$ tree mortality by human process (illegally exploited and affected by forest fires; ranging from 0 to 248 dead trees $\cdot$ ha $^{-1}$ )

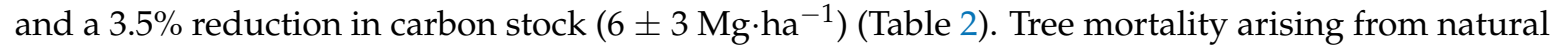
process (naturally fallen; ranging from 0 to 124 dead trees $\cdot$ ha $^{-1}$ ) resulted in a $53 \%$ of tree mortality (Table 2).

Table 2. Impacts of illegal selective logging and forest fires in tree mortality and forest carbon stock in the northern Brazilian Amazon.

\begin{tabular}{cccccc}
\hline \multirow{2}{*}{ Description } & \multicolumn{3}{c}{ Tree Mortality } & \multicolumn{2}{c}{ Forest Carbon Stock } \\
\cline { 2 - 6 } & $\begin{array}{c}\text { Density (Dead } \\
\text { Trees·ha }\end{array}{ }^{-\mathbf{1})}$ & $\begin{array}{c}\text { Total Dead Trees } \\
\text { in FI (30 ha) }\end{array}$ & $\begin{array}{c}\text { Percentage of } \\
\text { the FI (\%) }\end{array}$ & $\begin{array}{c}\text { Carbon Losses } \\
\mathbf{( M g ~ h a}^{-\mathbf{1}} \mathbf{)}\end{array}$ & $\begin{array}{c}\text { Percentage of } \\
\text { the FI (\%) }\end{array}$ \\
\hline Natural Process $^{1}$ & $21 \pm 3$ & 638 & 4.3 & - & - \\
Human Process $^{2}$ & $19 \pm 9$ & 575 & 3.9 & $6 \pm 3$ & 3.5 \\
\hline Total & $40 \pm 9$ & 1213 & 8.2 & $6 \pm 3$ & 3.5 \\
\hline
\end{tabular}

\footnotetext{
${ }^{1}$ Dead trees arising from natural processes (naturally fallen), where the reduction of the carbon stock will be slow, was not quantified in the present study; ${ }^{2}$ dead trees arising from human processes (illegally exploited and affected by forest fires), where the reduction of the carbon stock was fast, changing rates of gas exchange of the forest ecosystem in the short-term, proportional to the intensity of illegal selective logging and fire incidence. Mean values and $95 \%$ confidence intervals $\left(\mathrm{CI}_{95 \%}\right)$.
}

\subsection{Illegal Selective Logging and Forest Fires in the Southern Roraima}

Illegal selective logging and forest fires in forest areas were detected in $357 \mathrm{~km}^{2}(0.5 \%)$ of the mosaic area and $6 \mathrm{~km}^{2}(0.2 \%)$ within of Flona Anauá during the period 10/04/2015 to 01/10/2017 (Figures 7c and 8a-c; Table 3). This value was equivalent to $0.8 \%$ of the surveyed area (LOt). Forest disturbances caused by forest fires in non-forest areas totaled $34 \mathrm{~km}^{2}(0.1 \%)$ in the mosaic area, and 0.2 $\mathrm{km}^{2}(0.01 \%)$ within of Flona Anauá. Deforestation in forest areas was estimated at $796 \mathrm{~km}^{2}(1.2 \%)$ in the mosaic area, and $8 \mathrm{~km}^{2}(0.3 \%)$ within Flona Anauá. In non-forested areas, these values were much lower. Regions closer to roads (rural and BR-174), agrarian reform settlement projects (PA/INCRA), and private rural properties, where farmers and loggers with Authorizations of Deforestation (ADs) are located, were the most affected. 
Table 3. Areas affected by illegal selective logging and forest fires, forest disturbances (in non-forest areas), and deforestation in the northern Brazilian Amazon.

\begin{tabular}{cccccccc}
\hline \multirow{2}{*}{ Description } & \multicolumn{3}{c}{ Forest Areas $\left.\mathbf{( k m}^{2}\right)$} & \multicolumn{3}{c}{ Non-Forest Areas $\left(\mathbf{k m}^{2}\right)$} \\
\cline { 2 - 8 } & $\mathbf{L O t}^{1}$ & $\begin{array}{c}\text { Flona } \\
\text { Anauá }\end{array}$ & $\begin{array}{c}\text { Mosaic } \\
\text { Area }\end{array}$ & $\begin{array}{c}\text { Roraima } \\
\mathbf{( \% )}\end{array}$ & $\begin{array}{c}\text { Flona } \\
\text { Anauá }\end{array}$ & $\begin{array}{c}\text { Mosaic } \\
\text { Area }\end{array}$ & $\begin{array}{c}\text { Roraima }^{2} \\
(\%)\end{array}$ \\
\hline $\begin{array}{c}\text { Illegal selective logging and forest fires } \\
\text { Forest disturbances by forest fires }\end{array}$ & 2.8 & 6 & 357 & 0.16 & - & - & - \\
Deforestation & - & - & - & - & 0.2 & 34 & 0.01 \\
\hline Total & 8 & 8 & 796 & 0.35 & 0.1 & 152 & 0.07 \\
\hline
\end{tabular}

${ }^{1}$ Transitional ecosystems or ecotones (LOt $\left.=\mathrm{Ld} / \mathrm{Ds}\right) ;{ }^{2}$ Percentage of affected areas in the State of Roraima.

\subsection{Fire Incidence in Roraima (2016 to 2017) and Flona Anauá}

The surface area, or influence of forest fires of very high density $\left(8,397 \mathrm{~km}^{2}\right)$ were detected in the south-central region of Roraima during 2016 and 2017 (Figure 11a). The eastern region of Flona Anauá experienced a very high density of forest fires $\left(37 \mathrm{~km}^{2}\right)$ (Figure $\left.11 \mathrm{~b}\right)$, while the south-central region was the most affected by fires in Roraima (2016 and 2017) (Figure 12). The effective area of the forest fires was in $772 \mathrm{~km}^{2}(1.2 \%)$ of the mosaic area, and $8 \mathrm{~km}^{2}(0.3 \%)$ within Flona Anauá.

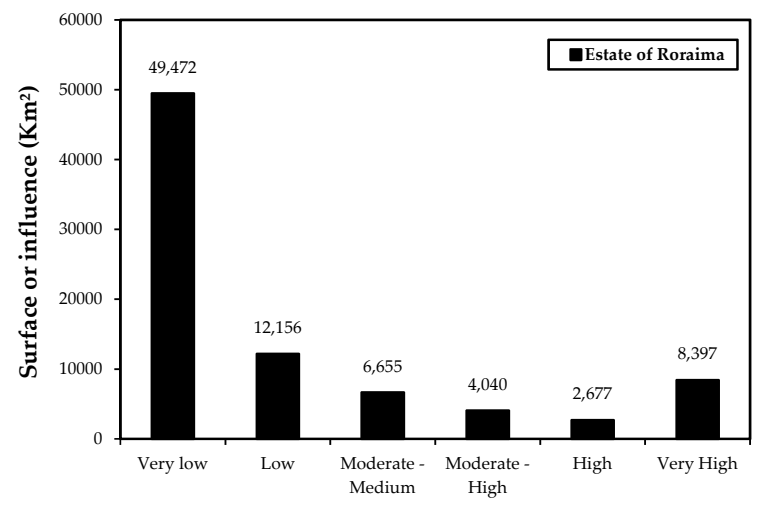

Density of forest fires - Period 2016 to 2017

(a)

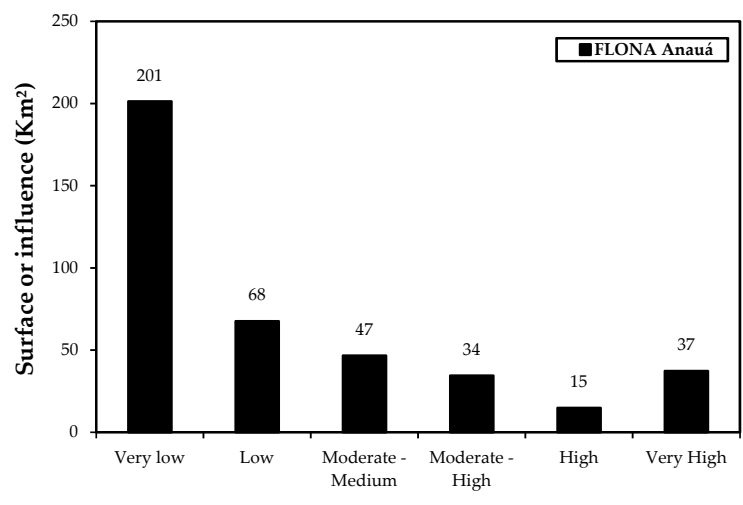

Density of forest fires - Period 2016 to 2017

(b)

Figure 11. Surface area or influence of forest fires in Roraima (2016 to 2017): (a) State of Roraima; (b) Flona Anauá.

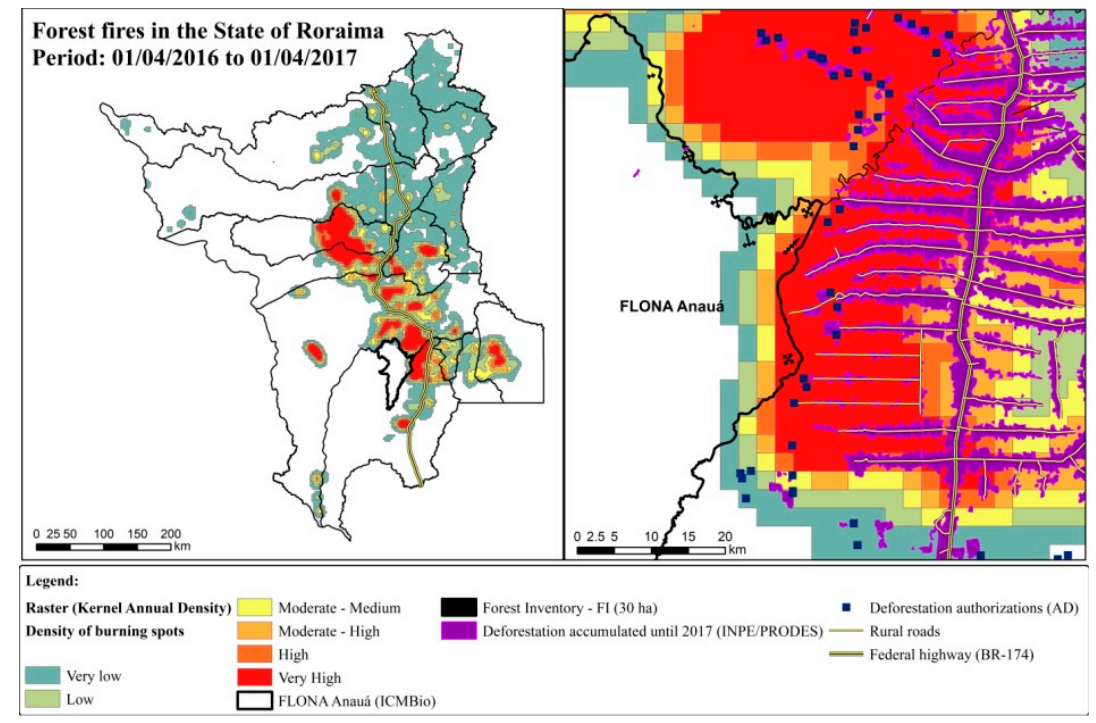

Figure 12. Surface area or influence of forest fires in Roraima (2016 to 2017) in the eastern region of the Flona Anauá. 


\subsection{Accuracy Assessment of Mapping Performed by CLASlite}

The overall accuracy (86\%) and Kappa coefficient (82\%) of the mapping performed by CLASlite were high (Table 4). The accuracy from the producer, which is the probability that the classifier (CLASLite algorithm) has labeled an image pixel as $\mathrm{C} 1$ (deforestation), when the ground truth identified that deforestation had occurred at that site, was higher than C2 (illegal selective logging), but both were considered accurate in mapping. Omission errors representing pixels that belonged to the ground truth class (in situ), but which the classification technique by CLASlite had failed to classify into the appropriate class, were higher for C2 (illegal selective logging) and C4 (non-forested areas).

Table 4. Accuracy assessment of the mapping performed by CLASlite in the affected areas for illegal selective logging, deforestation, and forest fires in the northern Brazilian Amazon.

\begin{tabular}{|c|c|c|c|c|c|c|c|c|c|c|}
\hline \multirow{2}{*}{\multicolumn{2}{|c|}{ Class $^{1}$}} & \multicolumn{5}{|c|}{ Validation $^{2}$ (Ground Truth - In Situ) } & \multicolumn{2}{|c|}{ Errors (\%) } & \multicolumn{2}{|c|}{ Accuracy (\%) } \\
\hline & & $\mathrm{C} 1$ & $\mathrm{C} 2$ & $\mathrm{C} 3$ & $\mathrm{C} 4$ & Total & Commission & Omission & Producer & User \\
\hline \multirow{5}{*}{ 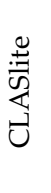 } & $\mathrm{C} 1$ & 89 & 8 & 0 & 14 & 111 & 20 & 11 & 89 & 80 \\
\hline & $\mathrm{C} 2$ & 0 & 75 & 0 & 1 & 76 & 1 & 25 & 75 & 99 \\
\hline & C3 & 5 & 12 & 98 & 2 & 117 & 16 & 2 & 98 & 84 \\
\hline & $\mathrm{C} 4$ & 6 & 5 & 2 & 83 & 96 & 14 & 17 & 83 & 86 \\
\hline & Total & 100 & 100 & 100 & 100 & 400 & & & & \\
\hline
\end{tabular}

Overall Accuracy $=86 \%$

Kappa Index $=82 \%$

${ }^{1} \mathrm{C} 1$ = Deforestation; C2 = Illegal selective logging; C3 = Forest areas; C4 = Non-forested areas; ${ }^{2}$ Control samples.

\section{Discussion}

The increased occurrence and severity of climate change has been intensified by human activities, contributing to changes in the Earth's surface temperature, changes in the water levels of rivers and oceans, increased greenhouse gases emissions, and a high mortality of fauna and flora [40]. Generally, a decrease in the variability of species' composition and alterations of forest structure have been observed in tropical ecosystems subjected to fires [41,42]. A study with the MODIS sensor revealed a 59\% increase in the occurrence of forest fires in the Brazilian Amazon (2000-2007), in areas where deforestation rates were being reduced, with severe implications for programs designed to reduce emissions from deforestation and forest degradation (REDD) [43].

The increase in forest fires in the Amazon in recent decades is strongly related to the drought-fire interaction, due to the high flammability of dry vegetation in the El Niño years, associated with the indiscriminate use of fire by humans. The increase in selective logging in Amazonia [7], to the detriment of the fall in deforestation rates (2004 to 2012) [3,44], has led to sawmills receiving an alternative constant supply of unauthorized timber [23-25,45]. This has been possible, because it is virtually invisible to low spatial resolution sensors (MODIS, Landsat, etc.) [7,13], and because this illegal activity can be concealed in a criminal manner with the use of multiple indiscriminate fires, resulting in large forest fires aimed at hindering the environmental monitoring of the origins of these fires. Another factor that contributes to increased illegal selective logging is the large migration of loggers and sawmills from the Brazilian states of Mato Grosso, Pará, and Rondônia, to Roraima. Roraima has been reported as a "new gold woodland", due to its large extent of forests, the low cost of the land, and the low environmental control of deforestation and selective logging. 
Souza et al. [46] mapped the deforestation and degradation in the Legal Amazon of Brazil during the period from 2000 to 2010, and estimated a decrease in the deforestation, and a reduction in forest disturbances in the State of Roraima. Different values were estimated for deforestation by INPE/PRODES [44] in the period from 2001 to 2016, and forest disturbances by INPE/DEGRAD [47] in the period from 2007 to 2016 (Figure 13). Our results were higher for deforestation $\left(796+152=948 \mathrm{~km}^{2}\right)$ than those estimated by INPE/PRODES [44], which was reported as $156 \mathrm{~km}^{2}$ in 2015, and $202 \mathrm{~km}^{2}$ in 2016 for the State of Roraima. In contrast, INPE/DEGRAD [47] reported a forest degradation of $235 \mathrm{~km}^{2}$ in 2015, and $2838 \mathrm{~km}^{2}$ in 2016 in the State of Roraima, values that were much higher than that found in the present study $\left(357+34=391 \mathrm{~km}^{2}\right)$, which only examined southern Roraima.

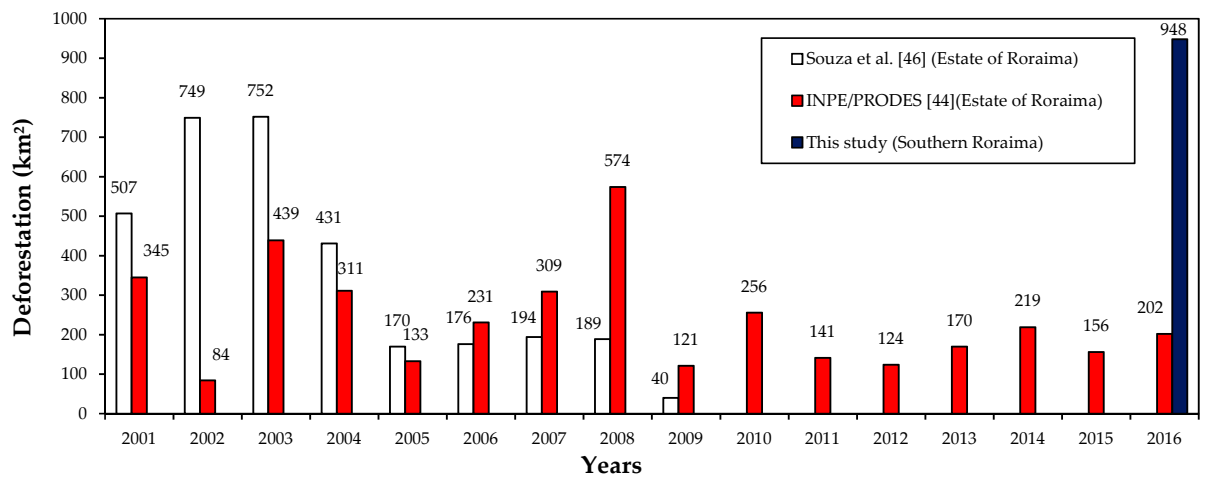

(a)

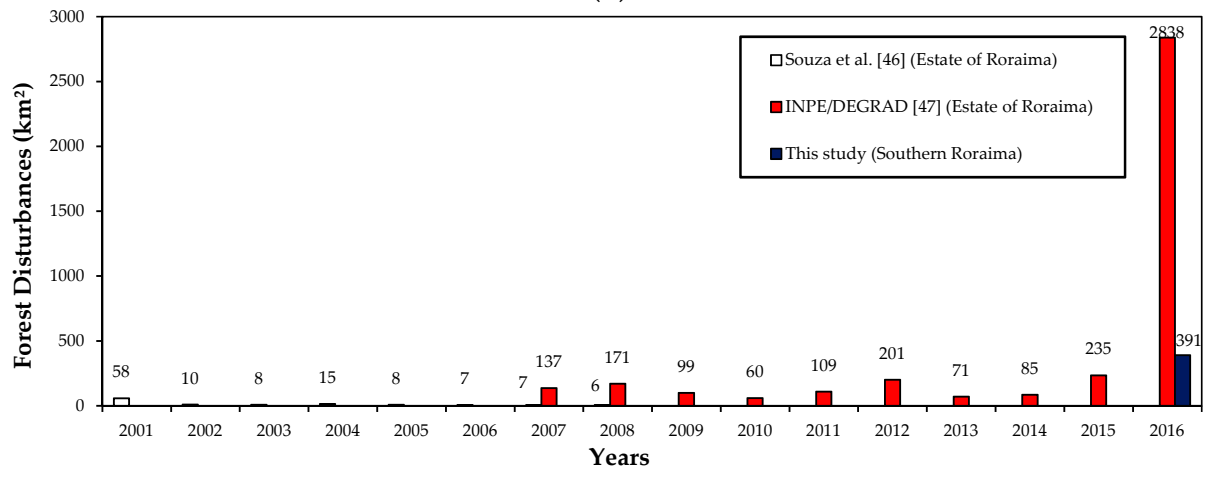

(b)

Figure 13. Annual rates for deforestation and forest disturbances for the State of Roraima: (a) Deforestation from Souza et al. [46] (2001 to 2010), INPE/PRODES [44] (2001 to 2016), and the present study (2016); (b) Forest disturbances from Souza et al. [46] (2001 to 2010), INPE/DEGRAD [47] (2007 to 2016), and the present study (2016).

Rates of natural tree mortality in Amazonian forests have generally been observed in the last few decades to be around $0.7 \%$ to $2 \%$ of the expected population density [8,48-50]. However, recent studies have shown that climatic changes intensified by human activities, including deforestation and forest degradation associated with forest fires, have contributed to an increase of tree mortality related to drought-fire interactions [3,41,51-53]. The monitoring of forest fires in Roraima since 1998 [18-20] has shown that tree mortality is strongly influenced by drought-fire interactions. These interactions can account for $36 \%$ and $78 \%$ of the mortality of smaller trees (DBH between 5 and $10 \mathrm{~cm}$ ), and between $8 \%$ and $21 \%$ of the mortality of larger trees (DBH $\geq 10 \mathrm{~cm}$ ) [40,41]. In the present study, illegal selective logging associated with forest fires and aggravated by severe El Niño droughts resulted in an $8.2 \%$ mortality of trees $\left(40 \pm 9\right.$ dead trees $\left.\cdot \mathrm{ha}^{-1}\right)$ and a $3.5 \%$ reduction in forest carbon stock $\left(6 \pm 3 \mathrm{Mg} \cdot \mathrm{ha}^{-1}\right)$ in the short-term (Table 2). These results confirm the hypothesis that in years of severe drought during El Niño (2015-2017), drought-fire interactions produced significant destruction in the Amazonian ecosystems. Drought increases fire susceptibility; after a forest is burned once, it is more likely to 
burn again, because a burned forest dries out more easily [54]. Illegal selective logging and forest fires increased tree mortality and reduced carbon stock by altering the natural of gas exchanges between plants and the atmosphere in the short-term, according to fire incidence [15-17] (Figures 14 and 15).

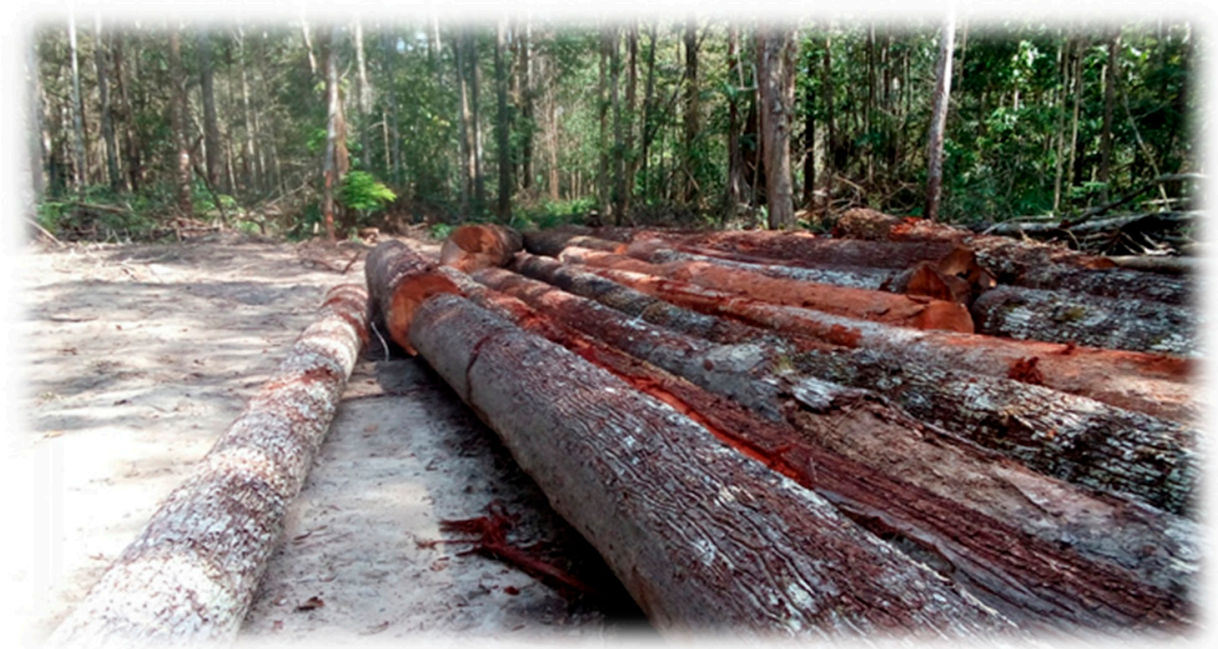

(a)

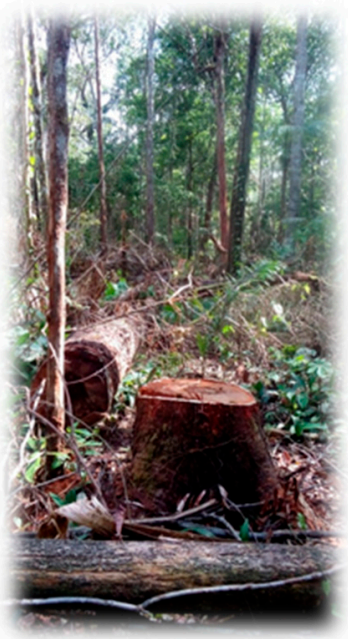

(b)

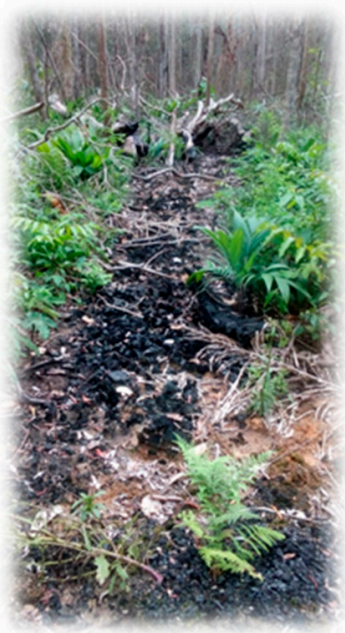

(c)

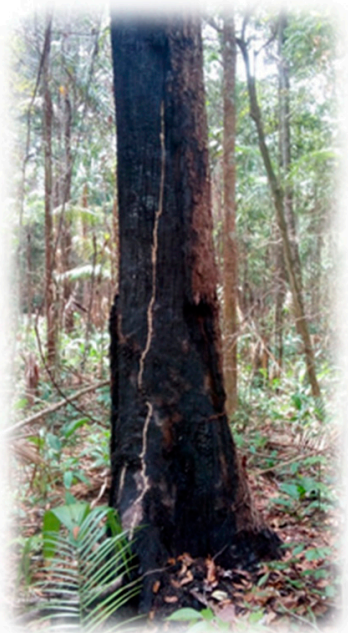

(d)

Figure 14. Illegal selective logging and forest fires in the northern Brazilian Amazon: (a) Illegal timber yard; (b) Illegal selective logging; (c) Forest fire scars; (d) Tree affected by forest fires. 


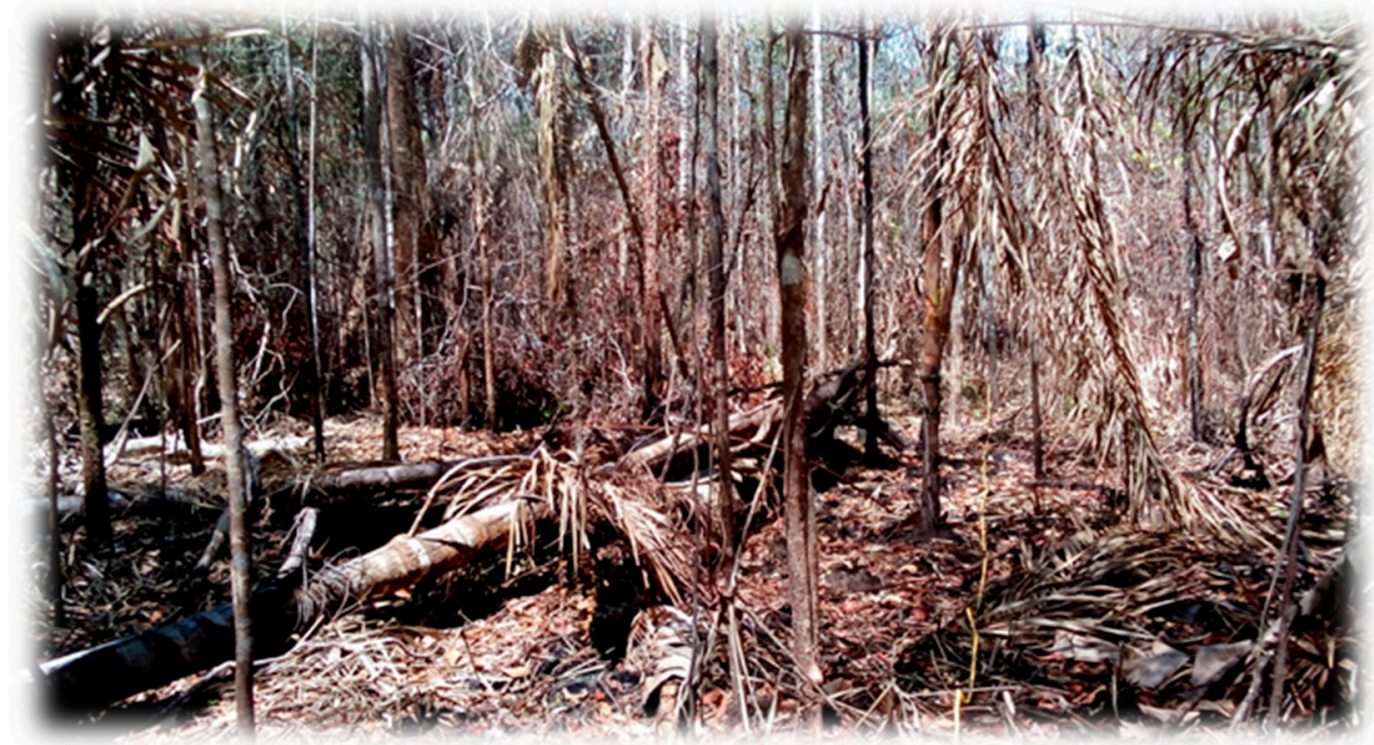

Figure 15. High tree mortality by illegal selective logging and forest fires in the northern Brazilian Amazon.

Spatial modeling of CLASlite $(30 \mathrm{~m})$ and INPE/Queimadas $(2472 \mathrm{~m})$ data in the present study was able to identify areas of occurrence and the influence of illegal selective logging associated with forest fires. This analysis delimited the range of possible regions that need priority actions in the fight against forest fires in the short-term, and also for medium and long-term planning in favor of environmental public policies. Although the spatial resolutions differ, this combination of data sources enables both point and general analyzes of these phenomena.

Although selective logging is not an immediate land-use change, it often leads to deforestation [54]. The patterns and trajectories of changes in land uses and land covers associated with fires in the Amazon, from native forest to cattle ranching and various agricultural uses, appears to be undergoing change in recent years. Declining rates of deforestation (2004 to 2012) have been accompanied by increasing rates of illegal selective logging [55]. The study of historical land use conversion and timber exploitation in Roraima from 2011 to 2016 [27], revealed that most deforestation authorizations (ADs) were not used for clear cutting in cattle ranching, or agriculture implementation (as registered in ADs). ADs were used as a means for disguising a large increase in illegal selective logging and forest fires in the northern Brazilian Amazon. We conclude that deforestation authorizations magnify the supply of legal and illegal timber for sawmills in Roraima. The reduced control of the chain of custody of the wood by environmental agencies, and the lack of public policies to encourage certified timber production through forest management favors the increase of illegal selective logging and forest fires in southern Roraima.

From 2002 to 2018, 1,497,713 $\mathrm{km}^{2}$ of the Brazilian Amazon were burned, and thousands of fires were recorded in the southern Roraima in 2016 [37], mainly in the region corresponding to the ADs (Figure 1, see Supplementary Materials: Figure S1). Tree mortality and reduced stocks of forest carbon within Flona Anauá were more intense in the eastern region, due to the proximity of the area to rural roads and a federal highway (BR-174), where agrarian reform settlement projects, private rural properties, and ADs are located. For years, the use of indiscriminate fire by humans has been part of the conversion of land use in Roraima [56]. The State of Roraima still has a large stock of forest biomass (see 176 p. [57]), but the association of selective logging and forest fires has contributed to the drastic loss of carbon in endemic Amazonian ecosystems, and increased greenhouse gas emissions [40].

The eastern region of Flona Anauá has great potential for the sustainable utilization of timber and non-timber resources (with multiple uses, e.g., palm hearts, fruits, seeds, leaves, roots, resins, etc.), but it requires a management plan that is allied with sustainable practices by PMFS, 
government subsidies on REDD, and forest certification. The altitude of the region is higher than 65 meters, favoring the occurrence of some of the most exploited timber species in Roraima, such as "maçaranduba"-Manilkara huberi (Ducke) A. Chev. and "angelim-ferro"—Dinizia excelsa Ducke $[8,27,33,45]$. Estimates of the mean tree density per hectare and the mean forest carbon stock per hectare from this forest inventory (FI) should be restricted to transitional ecosystems or ecotones (forest areas: $\mathrm{LOt}$, between Ld/Ds) only, and should not be applied to campinarana ecosystems (non-forested areas: $\mathrm{Lg}, \mathrm{Lb}, \mathrm{La}$ ) on the whole of Flona Anauá.

Unfortunately, due to the lack of public policies, endemic forest ecosystems in the northern Amazon remain vulnerable to deforestation and illegal selective logging and associated forest fires. Policies are required that encourage sustainable forest management, agriculture, and pasture without burning, intensive livestock farming, agroforestry systems, the recovery of degraded areas, and nature conservation. The high incidence of forest fires in this region is because of the ability of fires to penetrate these forests, due to the large volume of residuals (dead trees, branches, leaves, etc.) left by illegal selective logging $[7,13,15,16]$. This, coupled with the severity of the El Niño droughts, facilitates the occurrence of forest fires in the Amazon [3].

In soils with high sand contents (> 70\%), known as "white sand ecosystems", in transitional environments between campinarana and dense-canopy rainforest in Flona Anauá and Viruá National Park in southern Roraima [58,59], forest fires can result in large carbon losses. This is exacerbated by the long time that is required for forest restoration and replenishment of the vegetation carbon stock. Very sandy soils are susceptible to leaching and lower cation exchange capacity (see pp. 146-156 [60]), making it difficult to maintain high nutrient availabilities to plants. Soil carbon in these ecosystems percolates to groundwater, giving rise to the dark waters observed in the Itapará River and several igarapés of the west region of Flona Anauá. Where accessible to humans, the campinaranas have been used, unsustainably [21,56], for sand extraction, timber exploitation, agriculture, and livestock farming, leading to frequent forest fires [38].

In April 2018, a workshop was held, involving the Chico Mendes Institute of Biodiversity (ICMBio) and members of the Advisory Council to define the Management Plan for Flona Anauá, a proposal (environmental zoning) awaiting authorization from the Brazilian Ministry of the Environment (MMA). Scientific research should be undertaken in the long-term in the northern Brazilian Amazon, due to the extreme need for greater knowledge of biodiversity, hydrology, and carbon cycling in the face of increasing human pressure on natural resources. Currently, deforestation and illegal selective logging and associated forest fires represent the largest sources of both natural habitat loss and carbon emissions to the atmosphere in Brazil. The largest carbon stock in tropical vegetation is in Brazilian Amazonia [61]. It is fundamental to adopt public policies that are aimed at the preservation and sustainable use of natural resources in these fragile and endemic white sand ecosystems in the northern Brazilian Amazon.

\section{Conclusions}

Illegal selective logging and forest fires result in a strong increase in tree mortality, and drive carbon losses in the short-term, in transitional ecosystems or ecotones (LOt), between the Forested shade-loving campinarana (Ld) and Dense-canopy rainforest, submontane (Ds) in the northern Brazilian Amazon. The large amounts of forest residues generated by illegal selective logging has facilitated the penetration and propagation of fires into native forests, in the years of severe El Niño droughts (2015-2017). Illegal selective logging and forest fires can be considered a major threat to the maintenance of the environmental services provided by Amazonian forests.

Forest fires have been more frequent and severe in recent decades in the Amazon, mainly in El Niño years. The strong drought-fire interaction has contributed to the occurrence of mega fires in Roraima. The perpetuation of the traditional conversion of natural forests to pastures in order to expand extensive cattle ranching, with the indiscriminate use of fire by man, has contributed to the loss of floral and faunal habitats, with a significant increase in the emission of greenhouse 
gases. The combination of CLASlite with the monitoring of burning spots by INPE/Queimadas, with restrictions by forest physiognomies derived from a vegetation cover map from IBGE, contributed to our increased understanding of the spatialization, dynamics, and impact of the association between illegal selective logging and forest fires in the northern Brazilian Amazon.

Deforestation, illegal selective logging, and forest fires have been considered as major causes of tree mortality and forest carbon loss in the Brazilian Amazon. Public policies are needed to promote sustainable forest management, forest certification, agriculture, and pasture, without burning, intensive livestock farming, the recovery of degraded areas, reforestation, forestry, nature conservation, sustainable development, and valuation of the environmental services of Amazonian forests.

Supplementary Materials: The following are available online at http:/ / www.mdpi.com/1999-4907/10/1/61/s1, Figure S1: Monitoring of fires from January to March 2016 in the northern Brazilian Amazon by the National Institute of Space Research (INPE), Equations S1: The method described by Soares et al. [36] to estimate the mean values and the $95 \%$ confidence intervals $\left(\mathrm{CI}_{95} \%\right.$ by hectare and population, Equations S2: kernel density algorithm for calculating the density of the fires mapped by INPE/Queimadas, Table S1: Botanical list of the 171 dead trees (naturally fallen, selectively exploited illegally, and affected by forest fires) of the timber measurements in transitional ecosystems between the forested shade-loving campinarana (Ld) and the dense-canopy rainforest, submontane (Ds), in the National Forest (Flona) of Anauá, southern Roraima.

Author Contributions: All authors participated equally in the experimental design, data analysis, and manuscript preparation.

Funding: Coordenação de Aperfeiçoamento de Pessoal de Nível Superior (CAPES): 1451925.

Acknowledgments: Thanks goes to the financial support of the CAPES, INCT-Madeiras da Amazônia, and CNPq. We are grateful for the ICMBio/RR, FEMARH/RR, SEPLAN/RR, CIPA/RR and LMF/INPA. We are grateful the UERR (Forestry Engineering students) for support in data collection, especial Solange Augusta Costa.

Conflicts of Interest: The authors declare no conflict of interest.

\section{References}

1. Lewis, S.L.; Edwards, D.P.; Galbraith, D. Increasing human dominance of tropical forests. Science 2015, 349, 827-832. [CrossRef] [PubMed]

2. Lawrence, D.; Vandecar, K. Effects of tropical deforestation on climate and agriculture. Nat. Clim. Chang. 2015, 5, 27-36. [CrossRef]

3. Aragão, L.E.O.C.; Anderson, L.O.; Fonseca, M.G.; Rosan, T.M.; Vedovato, L.B.; Wagner, F.H.; Silva, C.V.J.; Silva Junior, C.H.L.; Arai, E.; Aguiar, A.P.; et al. 21st Century drought-related fires counteract the decline of Amazon deforestation carbon emissions. Nat. Commun. 2018, 9, 536. [CrossRef] [PubMed]

4. Chambers, J.Q.; Artaxo, P. Biosphere-atmosphere interactions: Deforestation size influences rainfall. Nat. Clim. Chang. 2017, 7, 175-176. [CrossRef]

5. Wright, J.S.; Fu, R.; Worden, J.R.; Chakraborty, S.; Clinton, N.E.; Camille, R.; Sun, Y.; Yin, L. Rainforest-initiated wet season onset over the southern Amazon. Proc. Natl. Acad. Sci. USA 2017, 114, 8481-8486. [CrossRef]

6. Artaxo, P.; Gatti, L.V.; Leal, A.M.C.; Longo, K.M.; Freitas, S.R.; Lara, L.L.; Pauliquevis, T.M.; Procópio, A.S.; Rizzo, L.V. Química atmosférica na Amazônia: A floresta e as emissões de queimadas controlando a composição da atmosfera amazônica. Acta Amaz. 2005, 35, 185-196. [CrossRef]

7. Asner, G.P.; Knapp, D.E.; Broadbent, E.N.; Oliveira, P.J.C.; Keller, M.; Silva, J.N. Selective Logging in the Brazilian Amazon. Science 2005, 310, 480-482. [CrossRef] [PubMed]

8. Condé, T.M. Avaliação dos Impactos na Vegetação após a Exploração Madeireira em Floresta Ombrófila Densa de Terra Firme Município de Caracaraí-RR. Master's Thesis, Universidade Federal de Roraima, Boa Vista, RR, Brazil, 2011.

9. Pereira, R., Jr.; Zweede, J.; Asner, G.P.; Keller, M. Forest canopy damage and recovery in reduced-impact and conventional selective logging in eastern Para, Brazil. For. Ecol. Manag. 2002, 168, 77-89. [CrossRef]

10. Johnson, M.O.; Galbraith, D.; Gloor, M.; Deurwaerder, H.; Guimberteau, M.; Rammig, A.; Thonicke, K.; Verbeeck, H.; Randow, C.V.; Monteagudo, A.; et al. Variation in stem mortality rates determines patterns of above-ground biomass in Amazonian forests: Implications for dynamic global vegetation models. Glob. Chang. Biol. 2016, 22, 3996-4013. [CrossRef] 
11. Fearnside, P.M. Quantificação do serviço ambiental do carbono nas florestas amazônicas brasileiras. Oecol. Bras. 2008, 12, 743-756. [CrossRef]

12. Nasi, R.; Putz, F.E.; Pacheco, P.; Wunder, S.; Anta, S. Sustainable Forest Management and Carbon in Tropical Latin America: The Case for REDD+. Forests 2011, 2, 200-217. [CrossRef]

13. Asner, G.P.; Broadbent, E.N.; Oliveira, P.J.C.; Keller, M.; Knapp, D.E.; Silva, J.N.M. Condition and fate of logged forests in the Brazilian Amazon. Proc. Natl. Acad. Sci. USA 2006, 103, 12947-12950. [CrossRef] [PubMed]

14. Nepstad, D.; McGrath, D.; Stickler, C.; Alencar, A.; Azevedo, A.; Swette, B.; Bezerra, T.; DiGiano, M.; Shimada, J.; Motta, R.S.; et al. Slowing Amazon deforestation through public policy and interventions in beef and soy supply chains. Science 2014, 344, 1118-1123. [CrossRef]

15. Cochrane, M.A. Fire science for rainforests. Nature 2003, 421, 913-919. [CrossRef]

16. Cochrane, M.A.; Laurance, W.F. Fire as a Large-Scale Edge Effect in Amazonian Forests. J. Trop. Ecol. 2002, 18, 311-325. [CrossRef]

17. Van Marle, M.J.E.; Field, R.D.; van der Werf, G.R.; Wagt, I.A.E.; Houghton, R.A.; Rizzo, L.V.; Artaxo, P.; Tsigaridis, K. Fire and deforestation dynamics in Amazonia (1973-2014). Glob. Biog. Cycles 2017, 31, 24-38. [CrossRef] [PubMed]

18. Barbosa, R.I.; Fearnside, P.M. Incêndios na Amazônia Brasileira: Estimativa da emissão de gases do efeito estufa pela queima de diferentes ecossistemas de Roraima na passagem do evento "El niño" (1997/98). Acta Amaz. 1999, 29, 513-534. [CrossRef]

19. Barni, P.E.; Pereira, V.B.; Manzi, A.O.; Barbosa, R.I. Deforestation and forest fires in Roraima and their relationship with phytoclimatic regions in the northern Brazilian Amazon. Environ. Manag. 2015, 55, 1124-1138. [CrossRef]

20. Fearnside, P.M.; Barbosa, R.I.; Pereira, V.B. Emissões de gases do efeito estufa por desmatamento e incêndios florestais em Roraima: Fontes e sumidouros. Rev. Agro@mbiente On-Line 2013, 7, 95-111. [CrossRef]

21. Adeney, J.M.; Christensen, N.L.; Vicentini, A.; Cohn-Haft, M. White-sand Ecosystems in Amazonia. Biotropica 2016, 48, 7-23. [CrossRef]

22. Guevara, J.E.; Damasco, G.; Baraloto, C.; Fine, P.V.A.; Peñuela, M.C.; Castilho, C.V.; Vicentini, A.; Cárdenas, D.; Wittmann, F.; Targhetta, N.; et al. Low Phylogenetic Beta Diversity and Geographic Neo-endemism in Amazonian White-sand Forests. Biotropica 2016, 48, 34-46. [CrossRef]

23. PF, Polícia Federal. Operação Salmo 96:12 prende servidores federais. Available online: http:/ / www.pf.gov. br/agencia/noticias/2012/maio/operacao-salmo-96-12-prende-servidores-federais (accessed on 23 April 2012).

24. PF. Polícia Federal. Operação Xilófagos combate o avanço do desmatamento na Amazônia Legal. Available online: http:/ / www.pf.gov.br/agencia/noticias/2014/12/pf-combate-o-avanco-do-desmatamento-naamazonia-legal (accessed on 25 May 2015).

25. IBAMA. Instituto Brasileiro do Meio Ambiente e dos Recursos Naturais Renováveis. O Ibama apreendeu 7.387 toras, o equivalente a cerca de 15 mil metros cúbicos de madeira, extraídas ilegalmente da Terra Indígena (TI) Pirititi, em Roraima. Available online: http: / /www.ibama.gov.br/noticias/436-2018/1434ibama-apreende-madeira-suficiente-para-carregar-mil-caminhoes-em-rr (acessed on 3 May 2018).

26. Brazil. Presidência da República. Lei no 9.985, de 18 de julho de 2000 (SNUC). Available online: http: / /www.planalto.gov.br/ccivil_03/leis/19985.htm (accessed on 7 May 2017).

27. Costa, S.A. Diagnóstico da Extração Madeireira no Estado de Roraima; Monography, Universidade Estadual de Roraima: Rorainópolis, RR, Brazil, 2016.

28. IBGE. Instituto Brasileiro de Geografia e Estatística. Manual Técnico da Vegetação Brasileira. Available online: https:/ / biblioteca.ibge.gov.br/visualizacao/livros/liv63011.pdf (accessed on 7 February 2014).

29. Higuchi, N.; dos Santos, J.; Ribeiro, R.J.; Minette, L.; Biot, Y. Biomassa da parte aérea da vegetação da floresta tropical úmida de terra-firme da Amazônia. Acta Amaz. 1998, 28, 153-166. [CrossRef]

30. Silva, R.P. Alometria, estoque e dinâmica da biomassa de florestas primárias e secundárias na região de Manaus (AM). Ph.D. Thesis, Instituto Nacional de Pesquisas da Amazônia/Universidade Federal do Amazonas, Manaus, AM, Brazil, 2007. 
31. Lima, A.J.N.; Suwa, R.; Ribeiro, G.H.P.M.; Kajimoto, T.; Santos, J.; Silva, R.P.; Souza, C.A.S.; Barros, P.C.; Noguchi, H.; Ishizuka, M.; et al. Allometric models for estimating above- and below-ground biomass in Amazonian forests at São Gabriel da Cachoeira in the upper Rio Negro, Brazil. For. Ecol. Manag. 2012, 277, 163-172. [CrossRef]

32. Gimenez, B.O.; dos Santos, L.T.; Gebara, J.; Celes, C.H.S.; Durgante, F.M.; Lima, A.J.N.; dos Santos, J.; Higuchi, N. Tree Climbing Techniques and Volume Equations for Eschweilera (Matá-Matá), a Hyperdominant Genus in the Amazon Forest. Forests 2017, 8, 154. [CrossRef]

33. Condé, T.M.; Tonini, H. Fitossociologia de uma Floresta Ombrófila Densa na Amazônia Setentrional, Roraima, Brasil. Acta Amaz. 2013, 43, 247-260. [CrossRef]

34. Higuchi, F.G.; Nakajima, N.Y.; Machado, S.A.; dos Santos, J.; Lima, A.J.N.; Higuchi, N. The use of Natural Fallen Trees in Mature Tropical Amazonian Forest for Volumetric Regression Analysis and Volume Equations Adjustment. Aust. J. Basic Appl. Sci. 2015, 9, 342-348.

35. Woortmann, C.P.I.B. Equações Alométricas, Estoque de Biomassa e Teores de Carbono e Nitrogênio de Campinaranas da Amazônia Central. Master's Thesis, Instituto Nacional de Pesquisas da Amazônia, Manaus, AM, Brazil, 2010.

36. Soares, C.P.B.; Paula Neto, F.; Souza, A.L. Dendrometria e Inventário Florestal, 2nd ed.; Editora UFV: Viçosa, Brazil, 2011; pp. 163-174.

37. Asner, G.P.; Knapp, D.E.; Balaji, A.; Páez-Acosta, G. Automated mapping of tropical deforestation and forest degradation: CLASlite. J. Appl. Remote Sens. 2009, 3, 033543. [CrossRef]

38. INPE/Queimadas. Instituto Nacional de Pesquisas Espaciais/Programa Queimadas. Monitoramento de focos de queimadas no Brasil. Available online: http:/ /www.inpe.br/queimadas/portal (accessed on 7 December 2018).

39. Jensen, J.R. Introductory Digital Image Processing - A Remote Sensing Perspective, 2nd ed.; Prentice Hall: Upper Saddle River, NJ, USA, 1996; pp. 247-252.

40. IPCC. Intergovernmental Panel on Climate Change. Climate Change 2014: Synthesis Report. Available online: http:/ / www.ipcc.ch/ (accessed on 9 May 2016).

41. Xaud, H.A.M.; Martins, F.S.R.V.; dos Santos, J.R. Tropical forest degradation by mega-fires in the northern Brazilian Amazon. For. Ecol. Manag. 2013, 294, 97-106. [CrossRef]

42. Numata, I.; Silva, S.S.; Cochrane, M.A.; d'Oliveira, M.V. Fire and edge effects in a fragmented tropical forest landscape in the southwestern Amazon. For. Ecol. Manag. 2017, 401, 135-146. [CrossRef]

43. Aragão, L.E.O.C.; Shimabukuro, Y.E. The Incidence of Fire in Amazonian Forests with Implications for REDD. Science 2010, 328, 1275-1278. [CrossRef]

44. INPE/PRODES. Instituto Nacional de Pesquisas Espaciais/Programa de Monitoramento por Satélites do Desmatamento por corte raso na Amazônia Legal. Taxas anuais de desmatamento da Amazônia Legal do Brasil. Available online: http:/ / www.obt.inpe.br/OBT/assuntos/programas/amazonia/prodes (accessed on 20 October 2018).

45. Crivelli, B.R.S.; Gomes, J.P.; Morais, W.W.C.; Condé, T.M.; Santos, R.L.; Bomfim Filho, O.S. Caracterização do setor madeireiro de Rorainópolis, sul de Roraima. Ciência da Madeira 2017, 8, 142-150. [CrossRef]

46. Souza, C.M.; Siqueira, J.V.; Sales, M.H.; Fonseca, A.V.; Ribeiro, J.G.; Numata, I.; Cochrane, M.A.; Barber, C.P.; Roberts, D.A.; Barlow, J. Ten-Year Landsat Classification of Deforestation and Forest Degradation in the Brazilian Amazon. Remote Sens. 2013, 5, 5493-5513. [CrossRef]

47. INPE/DEGRAD. Instituto Nacional de Pesquisas Espaciais/Programa de Mapeamento da Degradação Florestal na Amazônia Brasileira. Taxas anuais de degradação da Amazônia Legal do Brasil. Available online: http:/ / www.obt.inpe.br/OBT/assuntos/programas/amazonia/degrad (accessed on 20 October 2018).

48. Colpini, C.; Silva, V.S.M.; Soares, T.S.; Higuchi, N.; Travagin, D.P.; Assumpção, J.V.L. Incremento, ingresso e mortalidade em uma floresta de contato ombrófila aberta/estacional em Marcelândia, Estado do Mato Grosso. Acta Amaz. 2010, 40, 549-556. [CrossRef]

49. Laurance, W.F.; Nascimento, H.E.M.; Laurance, S.G.; Condit, R.; D’Angelo, S.; Andrade, A. Inferred longevity of Amazonian rainforest trees based on a long-term demographic study. For. Ecol. Manag. 2004, 190, 131-143. [CrossRef]

50. Higuchi, N.; Chambers, J.; dos Santos, J.; Pinto, A.C.M.; Silva, R.P.; Rocha, R.M.; Tribuzy, E.S. Dinâmica e balanço do carbono da vegetação primária da Amazônia Central. Floresta 2004, 34, 295-304. [CrossRef] 
51. Brando, P.M.; Balch, J.K.; Nepstad, D.C.; Morton, D.C.; Putz, F.E.; Coe, M.T.; Silvério, D.; Macedo, M.N.; Davidson, E.A.; Nóbrega, C.C.; et al. Abrupt increases in Amazonian tree mortality due to drought-fire interactions. Proc. Natl. Acad. Sci. USA 2014, 111, 6347-6352. [CrossRef] [PubMed]

52. Morton, D.C.; DeFries, R.S.; Nagol, J.; Souza, C.M., Jr.; Kasischke, E.S.; Hurtt, G.C.; Dubayah, R. Mapping canopy damage from understory fires in Amazon forests using annual time series of Landsat and MODIS data. Remote Sens. Environ. 2011, 115, 1706-1720. [CrossRef]

53. Silva, S.S.; Fearnside, P.M.; Graça, P.M.L.A.; Brown, I.F.; Alencar, A.; Melo, A.W.F. Dynamics of forest fires in the southwestern Amazon. For. Ecol. Manag. 2018, 424, 312-322. [CrossRef]

54. Davidson, E.A.; Araújo, A.C.; Artaxo, P.; Balch, J.K.; Brown, I.F.; Bustamante, M.M.C.; Coe, M.T.; DeFries, R.S.; Keller, M.; Longo, M.; et al. The Amazon basin in transition. Nature 2012, 411, 321-328. [CrossRef]

55. Brancalion, P.H.S.; Almeida, D.R.A.; Vidal, E.; Molin, P.G.; Sontag, V.E.; Souza, S.E.X.F.; Schulze, M.D. Fake legal logging in the Brazilian Amazon. Sci. Adv. 2018, 4, eaat1192. [CrossRef]

56. Urquiza, M.A.; Melo, V.F.; Francelino, M.R.; Schaefer, C.E.G.R.; Souza, E.; Barbosa, R.I.; Santiago, M.M.; Araújo, T.H.C.; Maia, S. Anthropic Processes and Land-Use Change During 33 Years in Roraima, Northern Amazonia. J. Agric. Sci. 2018, 10, 426-442. [CrossRef]

57. Barni, P.E.; Manzi, A.O.; Condé, T.M.; Barbosa, R.I.; Fearnside, P.M. Spatial distribution of forest biomass in Brazil's state of Roraima northern Amazonia. For. Ecol. Manag. 2016, 377, 170-181. [CrossRef]

58. Mendonça, B.A.F.; Fernandes Filho, E.I.; Schaefer, C.E.G.R.; Simas, F.N.B.; Vale Junior, J.F.; Lisboa, B.A.R.; Mendonça, J.G.F. Solos e geoambientes do Parque Nacional do Viruá e entorno, Roraima: Visão integrada da paisagem e serviço ambiental. Ciência Florestal 2013, 23, 427-442. [CrossRef]

59. Barbosa, R.I.; Keizer, E.; Pinto, F. Ecossistemas terrestres de Roraima: Área e modelagem espacial da biomassa. In Roraima: Homem, Ambiente e Ecologia; Barbosa, R.I., Melo, V.F., Eds.; Fundação Estadual do Meio Ambiente, Ciência e Tecnologia (Femact-RR): Boa Vista, RR, Brazil, 2010; pp. 347-367.

60. Novais, R.F.; Venegas, V.H.A.; Barros, N.F.; Fontes, R.L.F.; Cantarutti, R.B.; Neves, J.C.L. Fertilidade do Solo, 1st ed.; Editora SBCS: Viçosa, MG, Brazil, 2007; pp. 146-156.

61. Nogueira, E.M.; Yanai, A.M.; Fonseca, F.O.R.; Fearnside, P.M. Carbon stock loss from deforestation through 2013 in Brazilian Amazonia. Glob. Chang. Biol. 2015, 21, 1271-1292. [CrossRef] [PubMed] 